\title{
Inventory of Glaciers in the Shaksgam Valley of the Chinese Karakoram Mountains, 1970-2014
}

\author{
Haireti Alifu ${ }^{1, *(1)}$, Yukiko Hirabayashi ${ }^{2}$, Brian Alan Johnson ${ }^{3}$, Jean-Francois Vuillaume 4 (D), \\ Akihiko Kondoh ${ }^{5}$ and Minoru Urai ${ }^{6}$ \\ 1 Department of Civil Engineering, Shibaura Institute of Technology, 3-7-5, Toyosu, Kotoo-ku, \\ Tokyo 135-8548, Japan \\ 2 Department of Civil Engineering, Shibaura Institute of Technology, 3-7-5, Toyosu, Kotoo-ku, \\ Tokyo 135-8548, Japan; hyukiko@shibaura-it.ac.jp \\ 3 Institute for Global Environmental Strategies (IGES), 2108-11 Kamiyamaguchi, Hayama 240-0115, Japan; \\ johnson@iges.or.jp \\ 4 Institute of Industrial Science, The University of Tokyo, 4-6-1, Komaba, Meguro-ku, Tokyo 153-8505, Japan; \\ vuillaume@rainbow.iis.u-tokyo.ac.jp \\ 5 Center for Environmental Remote Sensing, Chiba University, 1-33, Yayoi-cho, Inage-ku, Chiba-shi, \\ Chiba 263-8522, Japan; kondoh@faculty.chiba-u.jp \\ 6 Geological Survey of Japan (GSJ), Advanced Industrial Science and Technology (AIST), 1-1-1 Umezono, \\ Tsukuba, Ibaraki 305-8560, Japan; urai-minoru@aist.go.jp \\ * Correspondence: hairetialifu@outlook.com; Tel.: +81-3-5859-8353
}

Received: 12 June 2018; Accepted: 18 July 2018; Published: 24 July 2018

\begin{abstract}
The Shaksgam Valley, located on the north side of the Karakoram Mountains of western China, is situated in the transition zone between the Indian monsoon system and dry arid climate zones. Previous studies have reported abnormal behaviors of the glaciers in this region compared to the global trend of glacier retreat, so the region is of special interest for glacier-climatological studies. For this purpose, long-term monitoring of glaciers in this region is necessary to obtain a better understanding of the relationships between glacier changes and local climate variations. However, accurate historical and up-to-date glacier inventory data for the region are currently unavailable. For this reason, this study conducted glacier inventories for the years 1970, 1980, 1990, 2000 and 2014 (i.e., a 10-year interval) using multi-temporal remote sensing imagery. The remote sensing data used included Corona KH-4A/B (1965-1971), Hexagon KH-9 (1980), Landsat Thematic Mapper (TM) (1990/1993), Landsat Enhanced Thematic Mapper Plus (ETM+) (2000/2001), and Landsat Operational Land Imager (OLI) and Thermal Infrared Sensor (TIRS) (2014/2015) multispectral satellite images, as well as digital elevation models (DEMs) from the Shuttle Radar Topography Mission (SRTM), DEMs generated from Advanced Spaceborne Thermal Emission and Reflection Radiometer (ASTER) images (2005-2014), and Advanced Land Observing Satellite (ALOS) World 3D $30 \mathrm{~m}$ mesh (AW3D30). In the year 2014, a total of 173 glaciers (including 121 debris-free glaciers) $\left(>0.5 \mathrm{~km}^{2}\right)$, covering an area of $1478 \pm 34 \mathrm{~km}^{2}$ (area of debris-free glaciers: $295 \pm 7 \mathrm{~km}^{2}$ ) were mapped. The multi-temporal glacier inventory results indicated that total glacier area change between 1970-2014 was not significant. However, individual glacier changes showed significant variability. Comparisons of the changes in glacier terminus position indicated that 55 (32 debris-covered) glaciers experienced significant advances ( 40-1400 m) between 1970-2014, and 74 (32 debris-covered) glaciers experienced significant advances ( 40-1400 m) during the most recent period (2000-2014). Notably, small glaciers showed higher sensitivity to climate changes, and the glaciers located in the western part of the study site were exhibiting glacier area expansion compared to other parts of the Shaksgam Valley. Finally, regression analyses indicated that topographic parameters were not the main driver of glacier changes. On the contrary, local climate variability could explain the complex behavior of glaciers in this region.
\end{abstract}


Keywords: Karakoram; Shaksgam Valley; Glacier Inventory; Corona; Hexagon; Landsat TM/ETM+; Landsat OLI/TIRS

\section{Introduction}

Glaciers are key indicators of climate change and provide important freshwater resources [1]. Glacier changes (e.g., advance or retreat) have a significant impact on physical (e.g., local and/or global sea levels), biological (e.g., global ocean circulation and marine ecosystems) and social (e.g., water resources and tourism) systems [1]. The Shaksgam Valley is located on the northern slope of the Karakoram mountain region and situated in the transition zone between the Indian monsoon and the Central Asia dry arid climate zones. Investigations of glacier changes over times in this area are particularly useful to understand the local climate variation because of the sparse climate records (especially at high altitudes) [2]. Meltwater from the Shaksgam glaciers helps sustain the people and natural ecosystems in the region, contributes to hydroelectric power generation, and provides important water resources for the Yarkant river, one of the tributaries of the Tarim river (main artery for the oases at the northern margin of the Taklimakan desert) [3]. On the other hand, the Shaksgam glaciers are also one of the largest sources of glacial lake outburst floods in this region [4,5]. Interestingly, glaciers in this region have been reported to be quite stable (even advancing) compared to the global trend of glacier retreat, which also known as the "Karakoram Anomaly" [6]. Therefore, long-term and frequent monitoring of the Shaksgam glaciers is crucial to try to predict their future behaviors (and future water supply) [2,7]. However, field investigation of the spatial extent of these glaciers is often difficult to perform because the glaciers are located in extremely cold regions or at high elevations that are inaccessible or inhospitable to humans. Furthermore, some of the glacier extents are large and change slowly or advance quickly (some of them have surge activity) [6,8,9]. Hence, repeated measurements are needed across the entire region and over a long time period. Thus, multi-temporal and up to date glacier inventories are necessary for accurate estimation of glacier mass balance and also for hydrological modelling analysis [7,10-12]. Fortunately, satellite remote sensing data and image analysis techniques provide the means for delineating the areal extent of glaciers in time and space over large areas [12].

Until now, except for publicly available glacier inventories such as the First Chinese Glacier Inventory (FCGI) [13], the Second Chinese Glacier Inventory (SCGI) [14], Glaciers_cci [15] and the Glacier Area Mapping for Discharge from the Asian Mountains (GAMDAM) glacier inventory [16], only two studies have investigated the glacier changes in the Karakoram region, which encompasses the Shaksgam Valley $[8,17]$. However, there are still gaps from these existing studies. For example, the FCGI was done using aerial photography (acquired from the 1970s) that contained extensive fresh snow cover, which hampered the detection of the actual glacier boundaries and resulted in overestimation of some of the glacier extents $[13,18]$ (see in Figure 1). In the Rankle et al. [17] study, in order to generated the updated glacier inventory (this inventory restricted to glaciers at least $3 \mathrm{~km}$ in length and more than $0.15 \mathrm{~km}^{2}$ in area), glacier outlines from RGI (Randolph Glacier Inventory) were manually improved using Landsat images acquired from 2009 to 2011. In the case of Bhambri et al. [8] study, recent glacier inventory (only surge-type glacier was inventoried) was generated using same method with Rankle et al. [17] study based on the most recent Landsat images (2013-2015) and high resolution of Google Earth images. However, for the past period, both studies were only mapped the glacier terminus position changes (not the entire glacier outline) using multi-mission Landsat images and Advanced Spaceborne Thermal Emission and Reflection Radiometer (ASTER) images [8,17]. In addition, rather than performing the systematic image co-registration, both studies assumed the horizontal shift between a pair of satellite images (half pixels to 2 pixels). Importantly, only $17-54 \%$ of the glacier (compared to total number of glacier in this study) was inventoried in these studies (Figure 2). Thus, there is still a lack of glacier extent information in the historical time, and such 
inventory was unavailable for the Shaksgam glacier in the 1980/1990 periods and glacier outlines in 1970s from FCGI had larger uncertainty. Moreover, glacier extent information was still missing in the recent period, due to updated glacier inventory [8,17] not mapping the glacier in the entire Shaksgam valley. On the other hand, the Glaciers_cci, GAMDAM and SCGI inventories were performed using Landsat Thematic Mapper (TM)/Landsat Enhanced Thematic Mapper plus (ETM+) images acquired around 2000/2001 and 2009. Hence, variations in the quality (and biases) of glacier boundaries in these different data sets may make them unsuitable for performing a detailed analysis of glacier variations over time [19]. Consequently, a regularly updated and more systematic/consistent glacier area change assessment of the area is needed. To overcome the major shortcomings of the existing studies and data sets, this study performs a multi-decade glacier inventory for the 1970, 1980, 1990, 2000 and 2014 time periods using satellite remote sensing data (multispectral imagery and digital elevation data). Finally, glacier changes and inter-glacier relationships were estimated, analyzed and discussed for the 1970-2014 periods based on a set of topographic/climate factors.

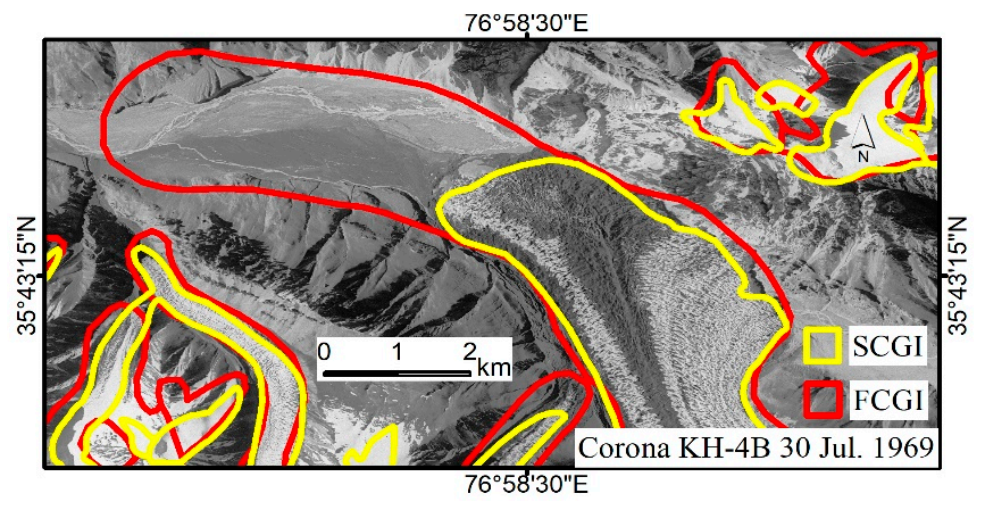

Figure 1. Example of overestimated glacier outlines by the First Chinese Glacier Inventory (FCGI). The overall location of this figure is shown in Section 2.1.

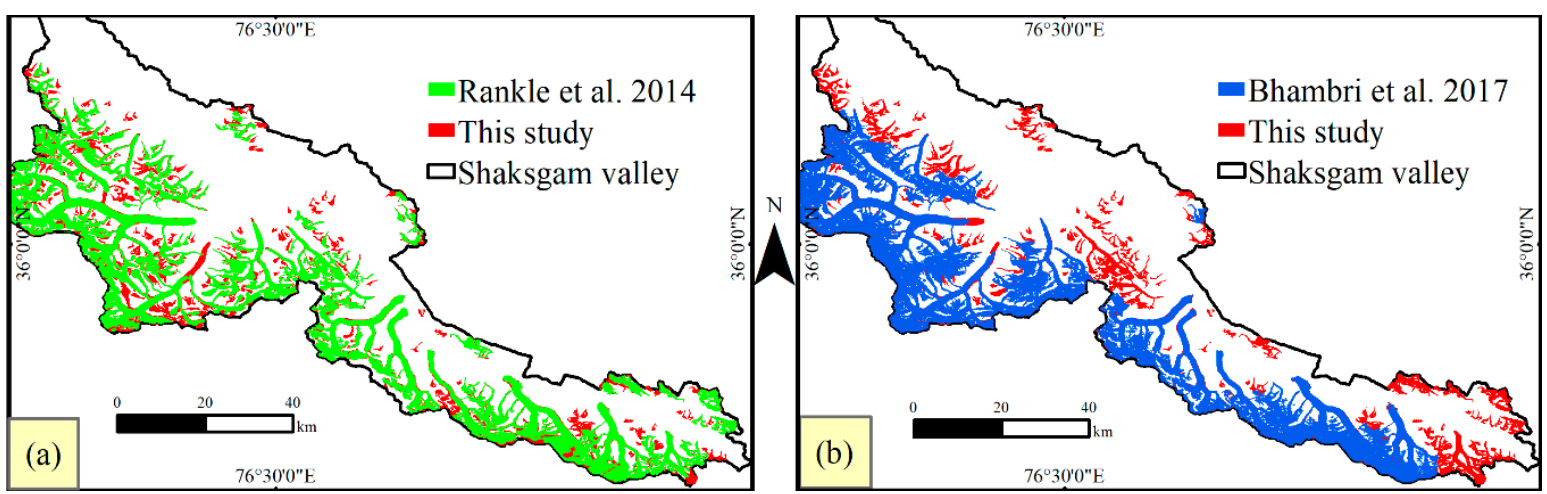

Figure 2. Comparisons of coverage of glacier inventories from previous studies with this study.

\section{Study Area and Datasets}

\subsection{Study Area}

The Shaksgam Valley (Figure 3) is located at the northern slope of the Chinese Karakoram mountain range in the south-west of the Xinjiang Uyghur Autonomous Region, China. It has an area of $4644 \mathrm{~km}^{2}$ and ranges in elevation from $3200 \mathrm{~m}$ to $8611 \mathrm{~m}$ (second highest peak in the world, K2). Due to the special location of the region, the Shaksgam Valley is under the complex influences of both the Indian monsoon and dry arid climate systems [20]. The westerlies (an important moisture source in winter) and advection of the moist air masses from the India monsoon are the main source 
of precipitation in this region [21]. The formation of large glaciers is a result of this special climate system (Figure 3). Therefore, the Shaksgam Valley has one of highest concentrations of large glaciers in mainland Asia [13]: e.g., eight glaciers are more than $50 \mathrm{~km}$ in length and more than 20 glaciers are at least $30 \mathrm{~km}$ long [13]. Debris-covered glaciers are also common in the Shaksgam valley, with most of the larger glaciers in this region being covered by thick debris [13]. However, there is no information about the exact debris thickness of these glaciers because of the inaccessible glacier terrain, which has resulted in almost no field observations $[13,22]$. The glaciers are an important contributor to the Indus and Yarkand rivers, and supports the livelihoods of around 130 million people [23]. Previous studies reported that Karakoram glaciers have stable or advancing terminus positions and surging behavior compared to the worldwide retreat of many mountain glaciers $[8,17,24,25]$.

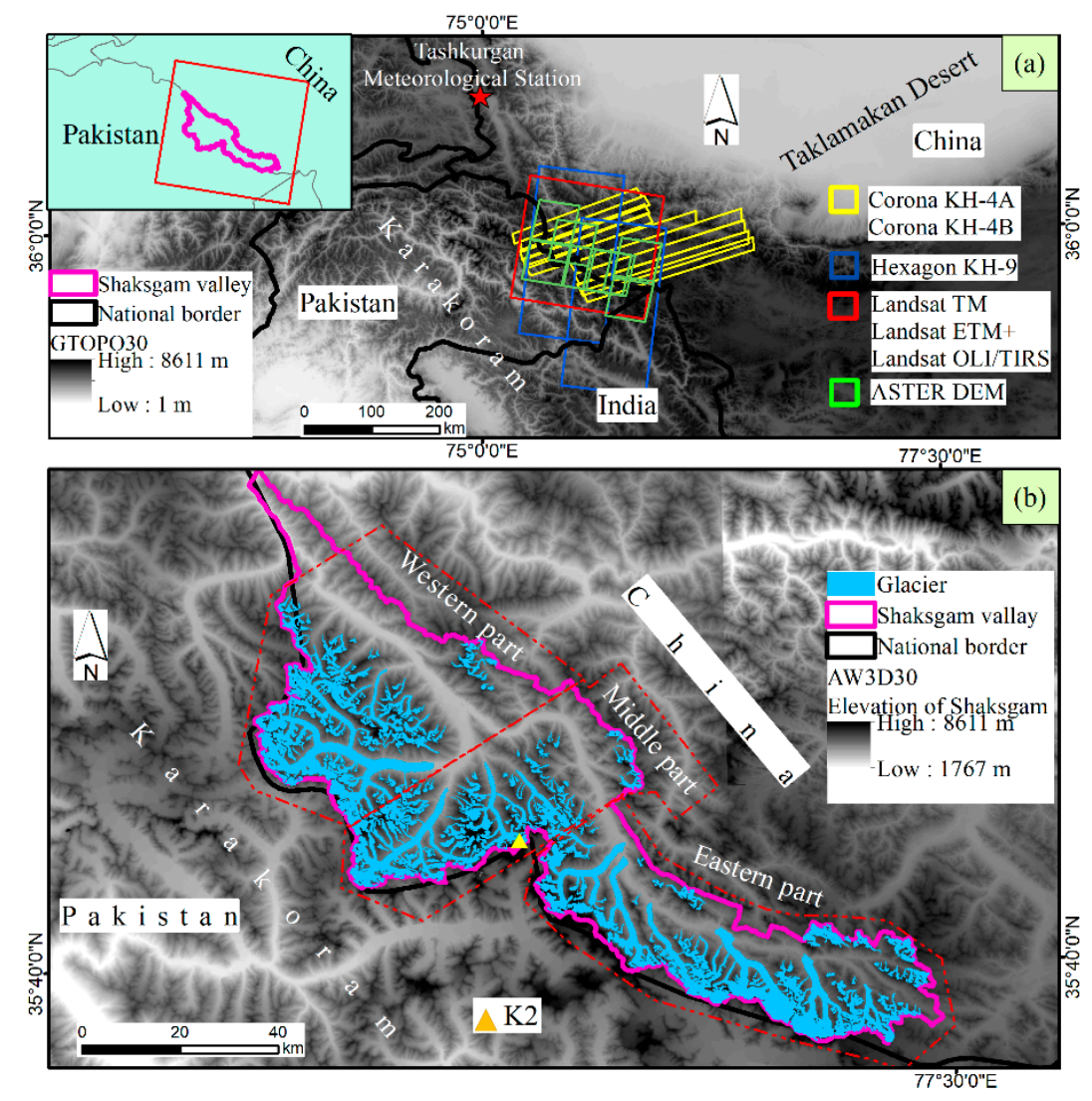

Figure 3. Utilized data coverage in this study (a) and the overall location of Shaksgam Valley (b).

\subsection{Datasets}

Cloud-free satellite images with minimal seasonal snow cover, acquired at the end of the ablation season, were used for glacier mapping in this study (see Table 1 for the image data information). A detailed description of the datasets is provided in the following sections. 
Table 1. Data used in this study.

\begin{tabular}{|c|c|c|c|c|c|}
\hline Satellite & Scenes ID & Date $(\mathrm{dd} / \mathrm{mm} / \mathrm{yy})$ & Resolution & Spectral Band & Utilization \\
\hline Corona KH-4A & DS1025-1039DA015 & $08 / 10 / 1965$ & \multirow{12}{*}{$3.5 \mathrm{~m}$} & \multirow{12}{*}{1 panchromatic band (PAN) } & \multirow{12}{*}{ Glacier inventory for 1970} \\
\hline Corona KH-4A & DS1044-1023DA019 & $04 / 11 / 1967$ & & & \\
\hline Corona KH-4B & DS1107-1104DA005 & $30 / 07 / 1969$ & & & \\
\hline Corona KH-4B & DS1107-1104DA003 & $30 / 07 / 1969$ & & & \\
\hline Corona KH-4B & DS1107-1104DA002 & $30 / 07 / 1969$ & & & \\
\hline Corona KH-4B & DS1107-1104DA004 & $30 / 07 / 1969$ & & & \\
\hline Corona KH-4B & DS1107-1104DA003 & $30 / 07 / 1969$ & & & \\
\hline Corona KH-4B & DS1107-1104DA005 & $30 / 07 / 1969$ & & & \\
\hline Corona KH-4B & DS1115-1088DF201 & $16 / 09 / 1971$ & & & \\
\hline Corona KH-4B & DS1115-1088DF202 & $16 / 09 / 1971$ & & & \\
\hline Corona KH-4B & DS1115-1088DF203 & 16/09/1971 & & & \\
\hline Corona KH-4B & DS1115-1088DF204 & $16 / 09 / 1971$ & & & \\
\hline Hexagon $\mathrm{KH}-9$ & DZB1216-500018L009001 & $22 / 07 / 1980$ & \multirow{2}{*}{$7.5 \mathrm{~m}$} & \multirow{2}{*}{1 PAN } & \multirow{2}{*}{ Glacier inventory for 1980} \\
\hline Hexagon KH-9 & DZB1216-500361L006001 & $16 / 09 / 1980$ & & & \\
\hline Landsat TM & ETP148R35_5T19900629 & $29 / 06 / 1990$ & $\begin{array}{l}28.5 \mathrm{~m} \\
120 \mathrm{~m}\end{array}$ & $\begin{array}{c}3 \text { visible (VIS), } 1 \text { near-infrared (NIR), } \\
2 \text { shortwave infrared (SWIR), } \\
1 \text { thermal infrared (TIR) }\end{array}$ & Glacier inventory for 1990 \\
\hline Landsat TM & LT51480351993188ISP00 & 07/07/1993 & $\begin{array}{c}30 \mathrm{~m} \\
120 \mathrm{~m}\end{array}$ & $\begin{array}{c}3 \text { VIS, } 1 \text { NIR, } 2 \text { SWIR, } \\
1 \text { TIR }\end{array}$ & $\begin{array}{l}\text { Additional information for } \\
\text { glacier identification (1990) }\end{array}$ \\
\hline \multirow{6}{*}{ SRTM } & SRTM3N35E075V2 & \multirow{6}{*}{$02 / 2000$} & \multirow{6}{*}{$30 \mathrm{~m}$} & & \multirow{6}{*}{$\begin{array}{l}\text { Additional information (Slope) } \\
\text { for glacier identification (1990) } \\
\text { Additional information (slope, } \\
\text { plan curvature and profile } \\
\text { curvature) for glacier } \\
\text { identification (2000) }\end{array}$} \\
\hline & SRTM3N35E076V2 & & & & \\
\hline & SRTM3N36E075V2 & & & & \\
\hline & SRTM3N36E076V2 & & & & \\
\hline & SRTM3N36E077V2 & & & & \\
\hline & SRTM3N35E077V2 & & & & \\
\hline \multirow{3}{*}{ Landsat ETM+ } & \multirow{3}{*}{ LE71480352000168SGS01 } & \multirow{3}{*}{$16 / 06 / 2000$} & $15 \mathrm{~m}$ & 1 PAN & \multirow{3}{*}{ Glacier inventory for 2000} \\
\hline & & & $30 \mathrm{~m}$ & 3 VIS, 1 NIR, 2 SWIR, & \\
\hline & & & $60 \mathrm{~m}$ & 1 TIR & \\
\hline \multirow[b]{2}{*}{ Landsat ETM+ } & \multirow[b]{2}{*}{ LE71480352001202SGS00 } & \multirow[b]{2}{*}{$21 / 07 / 2001$} & $15 \mathrm{~m}$ & 1 PAN & \multirow{2}{*}{$\begin{array}{l}\text { Additional information for } \\
\text { glacier identification (2000) }\end{array}$} \\
\hline & & & $30 \mathrm{~m}$ & 3 VIS, 1 NIR, 2 SWIR, & \\
\hline
\end{tabular}


Table 1. Cont.

\begin{tabular}{|c|c|c|c|c|c|}
\hline Satellite & Scenes ID & Date $(\mathrm{dd} / \mathrm{mm} / \mathrm{yy})$ & Resolution & Spectral Band & Utilization \\
\hline Landsat OLI/TIRS & LC81480352014166LGN00 & $15 / 06 / 2014$ & $\begin{array}{c}15 \mathrm{~m} \\
30 \mathrm{~m} \\
100 \mathrm{~m}\end{array}$ & $\begin{array}{c}1 \text { PAN } \\
3 \text { VIS, } 1 \text { NIR, } 2 \text { SWIR, } \\
1 \text { TIR }\end{array}$ & Glacier inventory for 2014 \\
\hline Landsat OLI/TIRS & LC81480352015185LGN00 & $04 / 07 / 2015$ & $\begin{array}{c}15 \mathrm{~m} \\
30 \mathrm{~m} \\
100 \mathrm{~m}\end{array}$ & $\begin{array}{c}1 \text { PAN } \\
3 \text { VIS, } 1 \text { NIR, } 2 \text { SWIR, } \\
1 \text { TIR }\end{array}$ & $\begin{array}{l}\text { Additional information for } \\
\text { glacier identification (2014) }\end{array}$ \\
\hline $\begin{array}{l}\text { Terra ASTER } \\
\text { Terra ASTER } \\
\text { Terra ASTER } \\
\text { Terra ASTER } \\
\text { Terra ASTER } \\
\text { Terra ASTER } \\
\text { Terra ASTER }\end{array}$ & $\begin{array}{l}\text { 148-101-5_051020_L1A } \\
\text { 148-101-4_110428_L1A } \\
\text { 149-100-7_110505_L1A } \\
\text { 147-102-2_110608_L1A } \\
\text { 148-101-5_120703_L1A } \\
\text { 148-100-2_140725_L1A } \\
\text { 148-101-2_140725_L1A }\end{array}$ & \begin{tabular}{l|}
$20 / 10 / 2005$ \\
$28 / 04 / 2011$ \\
$05 / 05 / 2011$ \\
$08 / 06 / 2011$ \\
$03 / 07 / 2012$ \\
$25 / 07 / 2014$ \\
$25 / 07 / 2014$ \\
\end{tabular} & $\begin{array}{l}15 \mathrm{~m} \\
30 \mathrm{~m} \\
90 \mathrm{~m}\end{array}$ & $\begin{array}{c}2 \text { VIS, } 2 \text { NIR } \\
6 \text { SWIR } \\
4 \text { TIR }\end{array}$ & $\begin{array}{l}\text { DEM generation and extracting } \\
\text { additional information (slope, } \\
\text { plan curvature and profile } \\
\text { curvature) for glacier } \\
\text { identification (2014) }\end{array}$ \\
\hline AW3D30 & $\begin{array}{l}\text { N035E076 } \\
\text { N035E077 } \\
\text { N036E075 } \\
\text { N036E076 }\end{array}$ & 2006-2011 & $30 \mathrm{~m}$ & & Glacier parameters extraction \\
\hline $\begin{array}{l}\text { Soviet Military Topo } \\
\text { maps }\end{array}$ & $\begin{array}{l}3 \text { maps } \\
7 \text { maps }\end{array}$ & $\begin{array}{l}1975 \\
1982\end{array}$ & $1: 100,000$ & & $\begin{array}{l}\text { Comparisons for glacier } \\
\text { inventory } 1970-1980\end{array}$ \\
\hline $\begin{array}{l}\text { GAMDAM Glacier } \\
\text { Inventory }\end{array}$ & & 2000 & $30 \mathrm{~m}$ & & $\begin{array}{l}\text { Comparisons for glacier } \\
\text { inventory } 2000\end{array}$ \\
\hline Glaciers_cci & & 2000 & $30 \mathrm{~m}$ & & $\begin{array}{l}\text { Comparisons for glacier } \\
\text { inventory } 2000\end{array}$ \\
\hline $\begin{array}{l}\text { Google Earth } \\
\text { Images }\end{array}$ & & 2014 & $2-5 \mathrm{~m}$ & & $\begin{array}{c}\text { Comparisons for glacier } \\
\text { inventory } 2014\end{array}$ \\
\hline
\end{tabular}




\subsubsection{Corona KH-4A/B}

For accurate delineation of the glaciers in the 1970s/1980s, declassified images from United States intelligence satellite missions such as Corona KH-4A/B and Hexagon KH-9 images were selected because of their high spatial resolutions (3-7 m) [18]. Corona KH-4AB contains a dual panoramic camera system (one camera looking forward and the other looking backward) with a separation angle of $30^{\circ}$, and offered the best ground resolution of about $1.8 \mathrm{~m}$ at nadir [26] (https:/ /lta.cr.usgs. gov/declass_1). High performance photogrammetric film scanners were used (scanning process does not apply geo-corrections) to create digital products of Corona images in four segments at 7-micron (3600 dpi) with photogrammetric quality, and the image files are stored in TIFF format (https: / / lta.cr.usgs.gov/declass_1). For this study, two Corona KH-4A and 10 Corona KH-4B (acquisition time: 1965-1971, Table 1) images were used for generation of a glacier inventory for the year 1970.

\subsubsection{Hexagon $\mathrm{KH}-9$}

The KH-9 mapping camera had a similar design to the National Aeronautics and Space Administration (NASA) Large Format Camera (LFC), with a $23 \times 46 \mathrm{~cm}$ frame format camera and $30.5 \mathrm{~cm}$ focal length [27]. There are crosses (reseau points) on the Hexagon images, 23 in the x-direction and 47 in the y-direction. Hexagon KH-9 images provide a footprint of $\sim 250 \times 125 \mathrm{~km}$ and have approximately about 6-9 m spatial resolution [27,28]. Hexagon KH-9 photographs were scanned without any geo-corrections in two segments at 7 microns ( $3600 \mathrm{dpi}$ ) and available in an 8-bit TIFF file format (https:/ / lta.cr.usgs.gov/declass_2). For this study, two Hexagon KH-9 images were utilized to produce glacier inventory around 1980 .

\subsubsection{Landsat Series Scenes, ASTER and DEMs}

Orthorectified Landsat series scenes (TM, ETM+ and Operational Land Imager and Thermal Infrared Sensor (OLI/TIRS)) (Table 1) and digital elevation models (DEMs) from the Shuttle Radar Topography Mission (SRTM) (used for glacier mapping in 1990/2000), as well as mosaicked DEMs generated from Advanced Spaceborne Thermal Emission and Reflection Radiometer (ASTER) stereo images acquired between 2005-2014 (representative the glacier geomorphometric parameters in 2014) were used for generation of glacier inventories in 1990, 2000 and 2014. Additional Landsat scenes from 1993 (Landsat TM), 2001 (Landsat ETM+) and 2015 (Landsat OLI/TIRS) (Table 1) were also used as complementary images during the digitization of the glacier outlines and to help differentiate seasonal fresh snow from permanent snow patches. $30 \mathrm{~m}$ spatial resolution SRTM and mosaicked ASTER DEMs were used to derive the geomorphometric parameters (GMP) such as slope, plan curvature and profile curvature, that are helpful for debris- covered glacier mapping [29,30]. Landsat TM, Landsat ETM+, and Landsat 8 images have six bands with $30 \mathrm{~m}$ spatial resolution in the visible (VIS), near-infrared (NIR) to shortwave infrared (SWIR) regions. Landsat ETM+ has a higher $(60 \mathrm{~m})$ spatial resolution thermal infrared (TIR) band compared to the Landsat TM TIR band $(120 \mathrm{~m})$ and Landsat OLI/TIRS TIR band (100 m). In addition, Landsat ETM+ and Landsat OLI/TIRS have a panchromatic band (PAN) with $15 \mathrm{~m}$ resolution that can be used to improve the glacier outlines derived from the semi-automatic processing technique.

\subsubsection{DEM Data Used for Extracting Glacier Topographic Parameters}

Glacier topographic parameters (e.g., minimum, maximum and median elevation, aspect, slope) have been found to be extremely useful for modelling, detection and change assessment of glaciers [31-33]. These topographic parameters have been extracted from the freely available SRTM or ASTER Global DEMs in past research. However, for this study we used the recently released (and also freely available) ALOS World 3D 30 m mesh (AW3D30) (http:/ / www.eorc.jaxa.jp/ALOS/en/aw3d30 / index.htm) for the calculation of glacier parameters because it has been reported to have higher vertical accuracy (4.40 m root mean square error (RMSE) height accuracy) compared to the SRTM and ASTER 
Global DEM products [34,35]. The AW3D30 was completed by Japan Aerospace Exploration Agency (JAXA) collaborating with Nippon Telegraph and Telephone (NTT) DATA Corporation recently, and the $30 \mathrm{~m}$ product was derived by resampling the $5 \mathrm{~m}$ resolution (not freely available) global DEM dataset generated from the high resolution Panchromatic Remote-sensing Instrument for Stereo Mapping (PRISM), which was onboard the JAXA Advanced Land Observing Satellite (ALOS) [36].

\subsubsection{Climate Data}

Cloud cover, temperature and precipitation data were used to assess the possible climate influences on glacier changes in the Shaksgam Valley. The percentage of cloud cover was obtained from a Global 1-km Cloud Cover observation database which is derived from 15 years of twice-daily Moderate Resolution Imaging Spectroradiometer (MODIS) imagery at 1-km resolution [37]. Mean annual temperature and precipitation were derived from the China Meteorological Forcing Monthly Dataset (CFMD). CFMD was produced by merging the China Meteorological Administration stations data, Tropical Rainfall Measuring Mission (TRMM) satellite precipitation analysis data (3B42), Global Energy and Water Cycle Experiment-Surface Radiation Budget (GEWEX-SRB) downward shortwave radiation data, Princeton forcing data, and Global Land Data Assimilation System (GLDAS) data. This dataset currently covers the period 1979-2010 and has a 0.1-degree spatial resolution [38,39].

\subsubsection{Validation Datasets}

The evaluation of glacier outlines was performed based on Soviet Military Topo maps (from 1975 and 1982), Glaciers_cci, GAMDAM glacier inventory data, and freely available high resolution Google Earth ${ }^{\mathrm{TM}}$ images. The georeferenced Soviet Military Topo maps (1:100,000 scale), which show the glacier covered areas in 1975 and 1982, were used to validate the glacier outlines in 1970 and 1980. The GAMDAM glacier inventory data was used for comparison with the glacier outlines delineated for the year 2000 in this study. The GAMDAM glacier inventory was produced through manual delineation using 356 Landsat ETM+ scenes from the period 1999-2003 (images from 2000/2001 were used for the study area), in conjunction with a DEM and high-resolution Google Earth ${ }^{\mathrm{TM}}$ images [16]. Glaciers_cci was generated using conventional band ratio (band3/band5) with manual correction of debris cover, seasonal snow, shadow, water based on the Landsat TM/ETM+ images from the year 1998-2002 [15]. Furthermore, for evaluation glacier outline in 2014, Google Earth ${ }^{\mathrm{TM}}$ images from similar acquisition dates were used. Google Earth ${ }^{\mathrm{TM}}$ images provide multi-temporal higher spatial solution images and corresponding DEM.

\subsubsection{Source of Datasets}

Corona, Hexagon, Landsat series images and SRTM data were downloaded from the USGS Earth Explorer (EE) (USGS EE; http:/ / earthexplorer.usgs.gov/). ASTER images (with minimal cloud cover and snow cover) were downloaded from the Japan Space Systems Earth Remote Sensing Division (ERSDAC) (http://gds.ersdac.jspacesystems.or.jp). AW3D30 was obtained from the JAXA Earth Observation Research Center (EORC) (http:/ / www.eorc.jaxa.jp/ALOS/en/aw3d30/data/index. $\mathrm{htm}$ ). Soviet Military Topo maps were purchased from "Topographic Maps of the World" (https: //mapstor.com/). Glaciers_cci was downloaded from the ESA CCI glaciers website (http:/ /www. esa-glaciers-cci.org/). GAMDAM Glacier Inventory data was downloaded from Nagoya University (http:/ / gamdam.cryoscience.net/). Global 1-km Cloud Cover observation database was available at http:/ / www.earthenv.org/cloud. The CFMD dataset can be obtained freely from http:/ / westdc. westgis.ac.cn/data/7a35329c-c53f-4267-aa07-e0037d913a21.

\section{Method for Generation of Multi-Temporal Glacier Inventories}

The generation of glacier inventories in this study follows the definitions developed within the GLIMS (Global Land Ice Measurements from Space) project. These definitions are adapted for the purpose of satellite-based glacier mapping based on official documents from the UNESCO (United 
Nations Educational, Scientific and Cultural Organization) guidelines for the compilation of the World Glacier Inventory [40]. For accurate estimation of glacier area change, only glaciers with areas larger than $0.5 \mathrm{~km}^{2}$ were inventoried in this study because glacier outlines derived from Landsat images (the main source of glacier inventories in 1990, 2000 and 2014) may be more than 25\% inaccurate for these very small glaciers due to the Landsat image pixel size [41]. The overall methodology for the generation of multi-temporal glacier inventories is shown in Figure 4, and the detailed processing steps are explained in the next Sections.

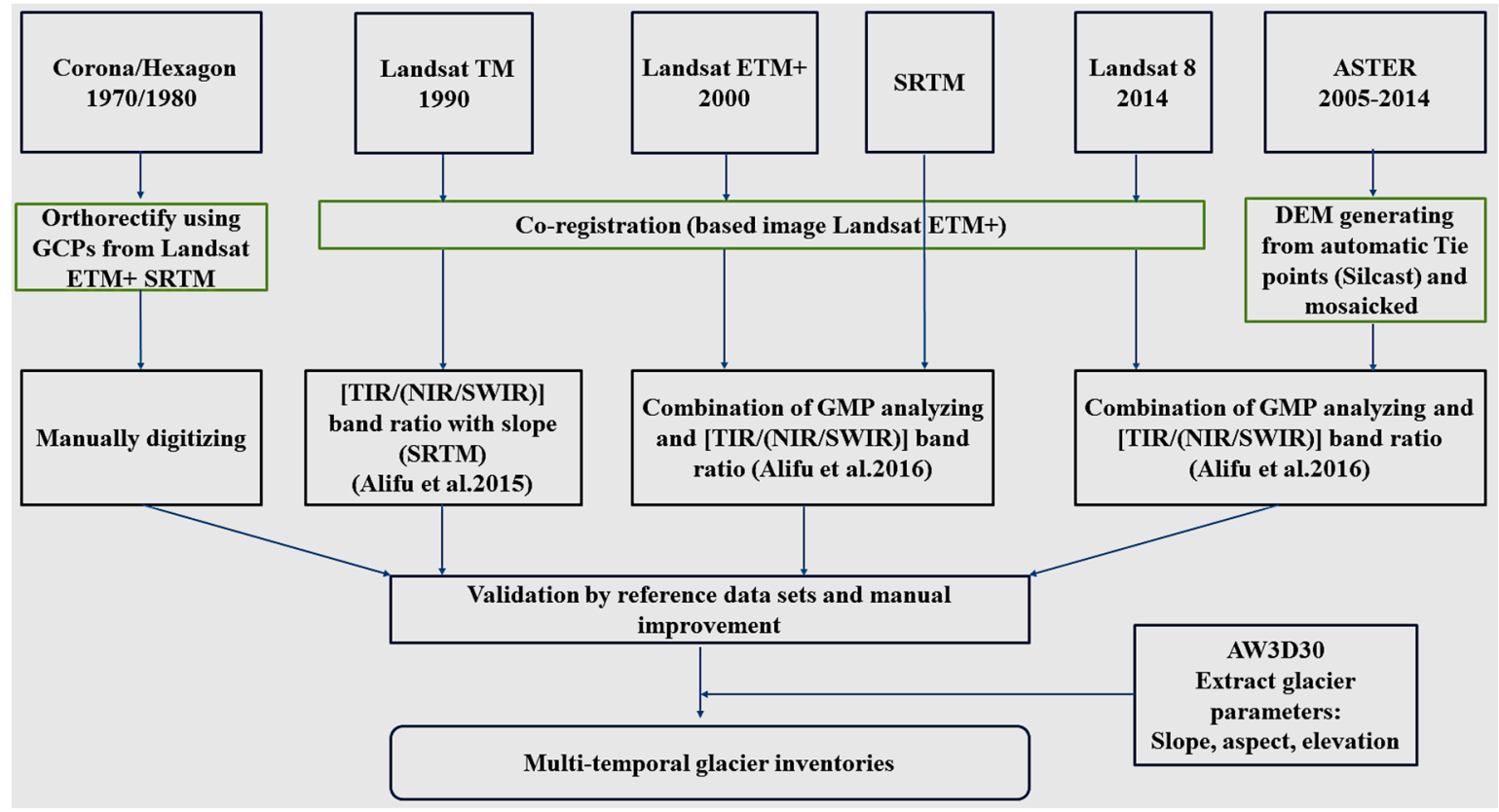

Figure 4. Schematic flowchart for generation of multi-temporal glacier inventories.

\subsection{Glacier Inventory $1970 / 1980$}

\subsubsection{Orthorectification of Corona Images}

Information about the Frame Ephemeris Camera, Orbital Data camera, and Spacecraft parameters are classified for Corona missions [18]. Therefore, a traditional image georeferencing tool was used to orthorectify Corona images. At first, individual Corona image segments were merged and subsetted for the 15 subsets of Shaksgam Valley. Then, all subsets were co-registered by a spline projective transformation, which was performed based on ground-control points (GCPs) from a panchromatic band of Landsat ETM+ (2000) (performed in ESRI (Environmental Systems Research Institute, Inc., Redlands, CA, USA) ArcGIS 10.2). Similar features such as stable rock features, river junctions, and road stream junctions from Corona and Landsat ETM+ (2000) images were used for collection of GCPs, and more than 200 GCPs were collected for each subset image. The final orthorectified Corona images had a $3.5 \mathrm{~m}$ spatial resolution.

\subsubsection{Orthorectification of Hexagon Images}

KH-9 Hexagon images were treated as regular aerial photographs for orthorectification purposes. Thus, the Hexagon images could be orthorectified using the aerial imagery tool of COSI-Corr (http: //www.tectonics.caltech.edu/slip_history/spot_coseis/index.html). Several steps were taken to orthorectify the Hexagon images. First, we made a mosaic of the two image halves of the Hexagon imagery. Second, we defined the interior orientation (IO) based on the reseau points on the Hexagon images. Third, we computed the exterior orientation (EO) based on the defined IO and selected GCPs (8 and 15 points) from a panchromatic band of Landsat ETM+ (2000) and SRTM. Fourth, orthorectified 
Hexagon images were produced by computing the mapping matrices using the optimized GCPs and EO. Finally, the orthorectified Hexagon images were co-registered again with the Landsat ETM+ (2000) imagery using a spline adjustment, and resampled to $7.5 \mathrm{~m}$ using ESRI ArcGIS. As a result, more than 250 GCPs were selected in the adjustment step.

\subsubsection{Manual Delineation of Glaciers Based on the Corona and Hexagon Images}

Manual digitization was the main method for generation of the glacier inventories in 1970 and 1980. Digitizing the debris-free glaciers was considerably easier because snow and ice present obvious brightness differences compared to the debris-covered glacier and surrounding objects. On the other hand, the boundaries of the debris-covered glaciers could be identified by their clearly recognizable geometric and topographic futures (ice crevasses, lateral and medial moraine) and their spectral differences (supraglacial ponds, exposed ice, river channel connect to the glacier terminus) from non-glacial areas in the Corona and Hexagon images (Figure 5).
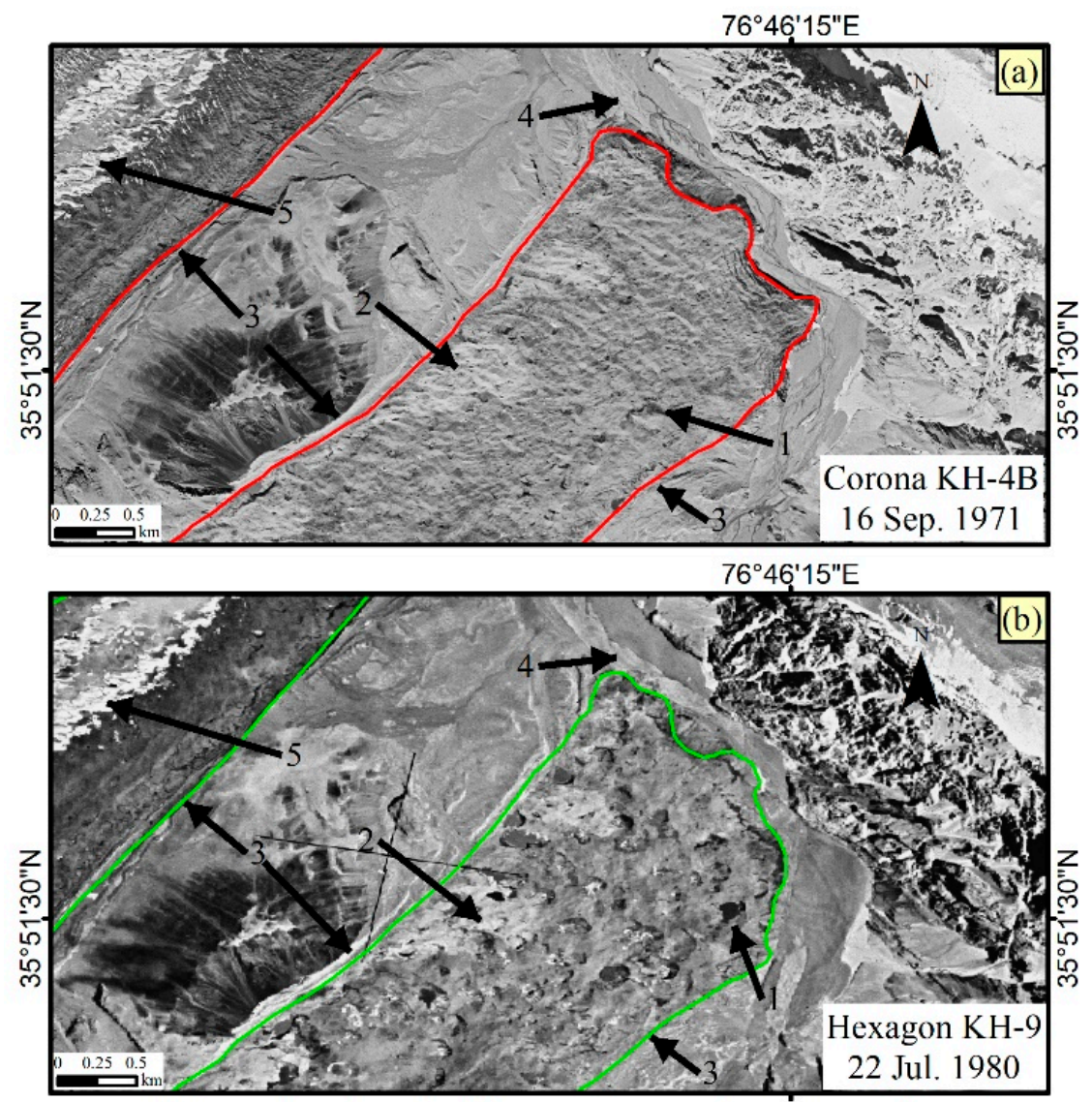

1.Supraglacial ponds 2.Ice crevasses 3. Lateral moraine 4. River channel connect to the glacier terminus 5. Exposed ice

Figure 5. Examples of manual digitizing the debris-covered glacier in this study. Debris-covered glacier boundary was identified based on distinct supraglacial debris futures (1-5) using Corona (a) and Hexagon images (b).

\subsection{Glacier Inventory 1990}

For the circa 1990 period, glaciers were delineated from Landsat TM images and a binary slope map $\left(<28^{\circ}\right)$ derived from SRTM, following the method proposed by Alifu et al. [29]. This method maps the glaciers based on a combination of a band ratio image [TIR/(NIR/SWIR)] and slope characteristics. The main advantage of the [TIR/(NIR/SWIR)] band ratio method is that it can utilize the benefits of 
both optical and thermal infrared data sets. The (NIR/SWIR) part of the equation helps to identify clean glacier-ice, whereas the TIR band contributes to distinguishing supraglacial debris (debris cover on the glacier) from the surrounding periglacial debris (debris cover on the outside of the glacier margin) region based on the thermal differences. However, the use of [TIR/(NIR/SWIR)] band ratio alone can lead to several inaccuracies for the supraglacial debris classes in the areas where bedrock valley walls are located in the shade and/or in higher elevation areas. Therefore, additional information based on slope is included to eliminate these errors. Finally, manual editing was performed to improve the final glacier outlines.

\subsection{Glacier Inventory 2000}

Glaciers inventory for the year 2000 was mapped based on a combination of [TIR/(NIR/SWIR)] band ratio and result from the geomorphometric analysis using Landsat ETM+ (2000) and SRTM [30]. Unlike the method used for the glacier map in 1990, additional GMP such as slope $\left(<28^{\circ}\right)$, plan curvature, and profile curvature, were computed from the SRTM data and then, integrated using the iterative minimum distance statistical clustering technique implemented into the SAGA software (SAGAGIS: http:/ / www.sagagis.uni-geottingen.de/html/index.php). Detailed steps of the methodology are presented in Alifu et al. [30]. Finally, manual improvements were conducted for final glacier outlines.

\subsection{Glacier Inventory 2014}

A similar approach to the glacier inventory generation (2000) was used for generating a glacier inventory in 2014 based on the Landsat 8 (2014) images and DEMs generated from ASTER (2005-2014) images. As explained previously, DEMs play a very important role in the accurate mapping of glaciers. However, the freely available global DEMs may not represent the current glacier terrain properties due to their less recent (or unknown) acquisition dates. For example, the SRTM DEM was generated from Space Shuttle Endeavour during the 11-day mission in February 2000. The other freely available global DEMs, ASTER Global DEM and AW3D30, were generated from stereo pairs images of unknown acquired dates, so, they also may not be representative of the glacier terrain properties in 2014 due to the changing topography of glaciers and the surrounding areas. Therefore, a more recent DEM was required for mapping glaciers circa 2014. Seven individual DEMs were generated from ASTER images using the SILCAST software, which can produce DEMs automatically without any ground control points (http:/ / www.silc.co.jp/en/products.html) [42]. The individual raw DEMs were edited to remove the unnatural peaks and no data values (very few pixels). Then, corrected raw DEMs were mosaicked to produce a DEM of the whole study area using cubic resampling method. The final vertical accuracy of the mosaicked DEM was evaluated using comparisons of 109 points on the glacier-free terrain from ASTER GDEM, SRTM, and AW3D30. The evaluation results showed that DEM generated from this study has relatively good accuracy compared to other DEMs (Table 2).

Table 2. Comparisons of 109 points from glacier-free terrain from Advanced Spaceborne Thermal Emission and Reflection Radiometer (ASTER) Digital Elevation Model (DEM) mosaic with reference DEMs.

\begin{tabular}{cccccc}
\hline DEMs & Total Points Number & Min & Max & Mean & DEM $_{\text {this study }}$ RMSE \\
\hline DEM $_{\text {this study }}$ & 109 & 3565 & 5360 & 4485 & $/$ \\
SRTM & 109 & 3580 & 5356 & 4484 & 13 \\
ASTER GDEM & 109 & 3570 & 5377 & 4480 & 12 \\
AW3DS30 & 109 & 3580 & 5336 & 4481 & 13 \\
\hline
\end{tabular}

Note: Root mean square error: RMSE is estimated from the difference between DEM $\mathrm{D}_{\text {this study }}$ and reference DEMs. 


\subsection{Complete Glacier Inventory}

To complete the glacier inventory, the glacier-ice masses need to be separated into individual glaciers. Additionally, glacier parameters such as glacier area, debris-covered area, minimum (min) elevation, maximum (max) elevation, median elevation, mean slope angle, and mean aspect were calculated.

For this, first the glacier outlines were separated into individual glaciers based on manual inspection of the satellite images, the hillshade images derived from DEMs, and Google Earth ${ }^{\mathrm{TM}}$ high-resolution images. Through the ice-division processing, seasonal snow cover outside the glacier margins was also removed. Following the separation of individual glacier outlines, the debris-free glaciers area and supraglacial debris area of each individual glacier was calculated in ArcGIS ("Calculate Geometry" tool). The min elevation, max elevation, median elevation, and mean slope angle were also extracted on a glacier by glacier basis based on the AW3D30 data in ArcGIS ("Zonal Statistics" tool). The mean aspect or orientation of the glacier surface was calculated as the arctangent of the quotient of the sums of aspect sines and cosines of each of the glacier's DEM grid cells $[43,44]$. Min elevation points were manually edited to the correct position and deleted if there were duplicate points (having the same elevation value). Then, in order to detect the glacier terminus change, spatial joins were performed in ArcGIS to calculate the distance between the two min elevations of points of each glacier in each time period.

\section{Accuracy Assessment and Error Estimation}

The potential errors of multi-temporal analysis come mainly from positional and mapping errors [45]. Co-registration of Landsat images was performed using ENVI software (Exelis Visual Information Solutions, USA) based on area-based matching method. The co-registration result showed a mean horizontal shift of about 0.35 pixel $(10.5 \mathrm{~m})$ for the Landsat TM images and, 0.25 pixel $(7.5 \mathrm{~m})$ for Landsat ETM+ and the Landsat OLI/TIR images. On the other hand, to assess positional accuracy for Corona and Hexagon images, 8-25 common location points such as river junctions and stable rocks were identified. Root mean square error (RMSE) of identified features (control points) was calculated by ArcMap (ESRI, USA) georeferencing tool using zero-order polynomial transformations (which is commonly used when the data is already georeferenced, but a small shift will better line up the data). RMSE of these features in each images showed that there was approximately 1.8 pixels $(6.3 \mathrm{~m})$ and 1.3 pixels $(9.9 \mathrm{~m})$ horizontal shift for Corona and Hexagon images. In this study, the uncertainty of glacier outlines was estimated by the buffer method recommended by Bolch et al. [45]. Hence, to estimate the uncertainty of glacier outlines, $6.3 \mathrm{~m}, 9.9 \mathrm{~m}, 10.5 \mathrm{~m}$ and $7.5 \mathrm{~m}$ buffer sizes were selected for the Corona, Hexagon, Landsat TM, and Landsat ETM and Landsat OLI/TIRS images, respectively. As a result, the mean uncertainty of the delineated glacier area was estimated as $2 \%$ for the Corona images, 3\% for the Hexagon images, $4.6 \%$ for Landsat TM and $2.4 \%, 2.3 \%$ for the Landsat ETM+ and Landsat OLI/TIRS images (Table 3). The uncertainty of glacier area changes between each period was calculated from the uncertainty of the two differenced extents (Table 3) [46]. On the other hand, we estimated the errors in glacier terminus change (Table 3) based on the Equation (1), which proposed by Hall et al. [47]:

$$
E=\sqrt{a^{2}+b^{2}}+e
$$

where; $E=$ error in glacier terminus change, $a=$ pixel resolution of imagery a, $b=$ pixel resolution of imagery $b, e=$ horizontal shift (Note that significant glacier change is determined when rate of glacier changes is larger than estimated errors (Figures 8 and 12-14)). 
Table 3. Error estimates for area (year), area change (period) and glacier terminus change (period).

\begin{tabular}{ccccc}
\hline Year & Error $_{\text {area }}$ Year (\%) & Period & Error $_{\text {area }}$ Period (\%) & Error $_{\text {terminus }}$ Period $(\mathbf{m})$ \\
\hline 1970 & 2.0 & $1970-1980$ & 3.5 & 20.0 \\
1980 & 2.9 & $1980-1990$ & 4.3 & 42.0 \\
1990 & 3.2 & $1990-2000$ & 4.0 & 52.0 \\
2000 & 2.4 & $2000-2014$ & 3.3 & 50.0 \\
2014 & 2.3 & $1970-2014$ & 3.0 & 37.0 \\
\hline
\end{tabular}

In addition to positional errors, mapping errors of glacier outlines are a key source of uncertainty for glacier change monitoring. In our study, the degree of mapping error for each inventory was evaluated visually using the Soviet Military Topo maps (for the results from 1970 and 1980),

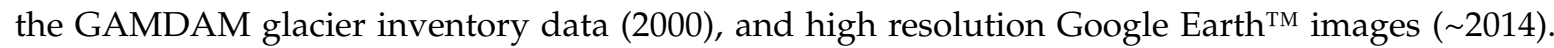
Unfortunately, no appropriate reference data was found for visual validation of glacier outlines in 1990. Finally, visual comparisons show the glacier boundaries generated from this study were quite similar to reference datasets (Figure 6), and also our estimates of uncertainties were of a similar range to those of the previous studies $[3,46,48]$.
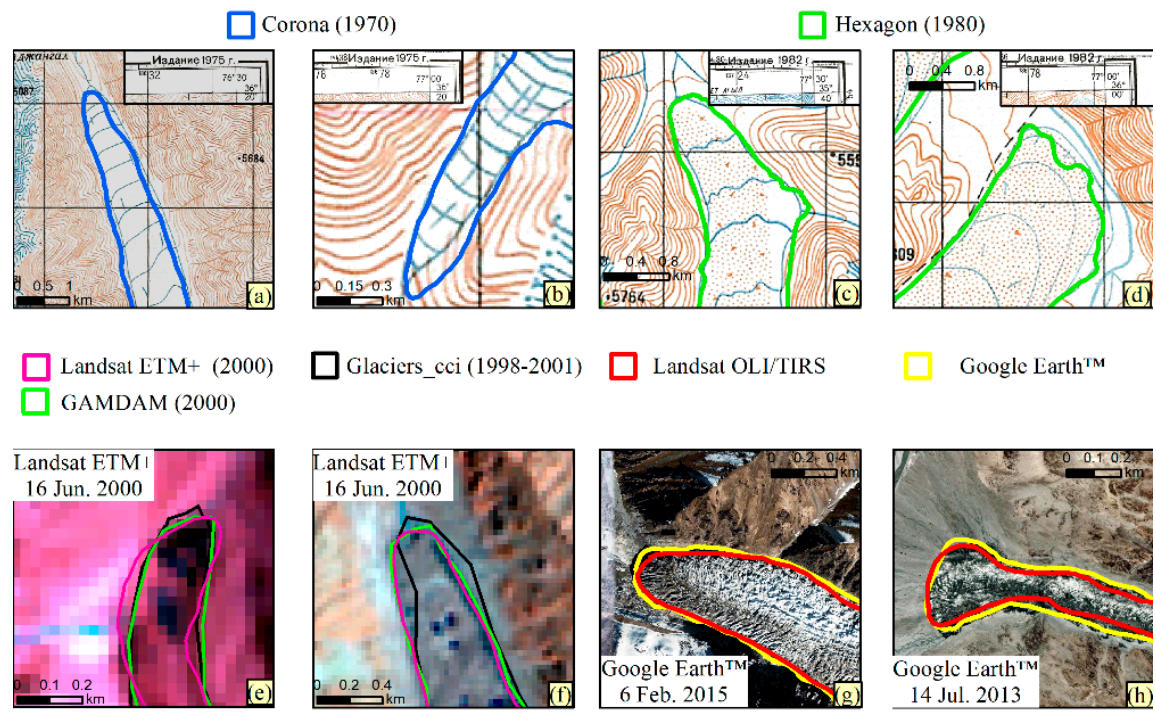

Figure 6. Examples of visual comparisons of glacier outlines derived from this study and references such as Soviet Military Topo maps (a-d), Glacier Area Mapping for Discharge from the Asian Mountains

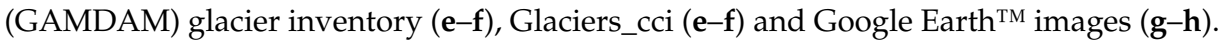

\section{Results}

\subsection{Updated Glacier (2014) Inventory and Glacier Characteristics}

The glacier inventory in 2014 yielded 173 glaciers (including 121 of debris-free glaciers), covering an area of $1478 \pm 34 \mathrm{~km}^{2}$ (debris-free glacier covering an area of $295 \pm 7 \mathrm{~km}^{2}$ ); 52 glaciers had debris cover on the ablation zones, covering an area of $128 \pm 3 \mathrm{~km}^{2}$. A similar number of glaciers were distributed in each sub-region (Figures $3 \mathrm{~b}$ and $7 \mathrm{c}$ ). However, the eastern part (40\% of total glacier area) of the Shaksgam Valley had the highest glacierized area, followed by the western part (37\% of total glacier area) and the middle part ( $23 \%$ of total glacier area) (Figure $7 \mathrm{c}$ ). About $8.6 \%$ of the total glacier area was covered by debris. Glaciers located in western part of the study area had the largest debris covered areas, followed by the middle and eastern parts. The elevations of glacier terminus positions ranged from 3972 to $5922 \mathrm{~m}$, with an average of approximately $4960 \mathrm{~m}$. The average median 
elevation of the glaciers was approximately $5578 \mathrm{~m}$. The mean slope of the glaciers overall in 2014 was $26^{\circ}$ (Table 4).

In terms of the sizes of individual glaciers, $36 \%$ of glaciers were $0.5-1 \mathrm{~km}^{2}$ in size, covering $3.1 \%$ of the total glacier area (Figure 7a). The highest number of glaciers (45\%) were $1-5 \mathrm{~km}^{2}$ in size, covering $11.5 \%$ of the total glacier area. Hence, $81 \%$ of glaciers were smaller than $5 \mathrm{~km}^{2}$, but they covered less than $15 \%$ of the total glacier area (Figure $7 \mathrm{a}$ ). On the other hand, the eight largest glaciers (greater than $50 \mathrm{~km}^{2}$ and smaller than $400 \mathrm{~km}^{2}$ ) covered $65 \%$ of the total glacierized area. The distribution of glacier orientations shows that most of the glaciers faced north (N) (37\%), north-east (NE) (21\%), and north-west (NW) (15\%), and they represented $43 \%, 39 \%$, and $8 \%$ of total glacier area, respectively (Figure $7 b$ ).

On average, the size of debris-free glaciers was greater in the eastern part of the Shaksgam Valley than in the other sub-regions (Figure $7 \mathrm{c}$ ). About $65 \%$ of the debris-free glaciers were $0.5-5 \mathrm{~km}^{2}$ in size, and they were mostly orientated in the N and NE directions (Figure 7b). On the contrary, around 30\% of the glaciers belonged to debris-covered glacier type, and they made up to $80 \%$ of total glacier area in the Shaksgam Valley (Figure 7a). Most of the debris-covered glaciers were oriented towards the NE, $\mathrm{N}$ and NW directions. In general, the glacier sizes as well as the range between the glacier min-max elevations were smaller for debris-free glaciers than for the debris-covered glaciers (Figure 6a and Table 4). On the other hand, the median elevation and terminus elevation of debris-free glaciers were higher than for debris-covered glaciers (Table 4). This demonstrated that the debris-covered glaciers typically had larger ablation areas than the debris-free glaciers. The larger glaciers (most of them belong to debris-covered glacier) in this region tended to expand to lower altitudes (longer length and relatively gentle slope), in contrast, smaller glaciers termini located at higher altitude (shorter length and relatively steeper slopes) (Figure 7a).
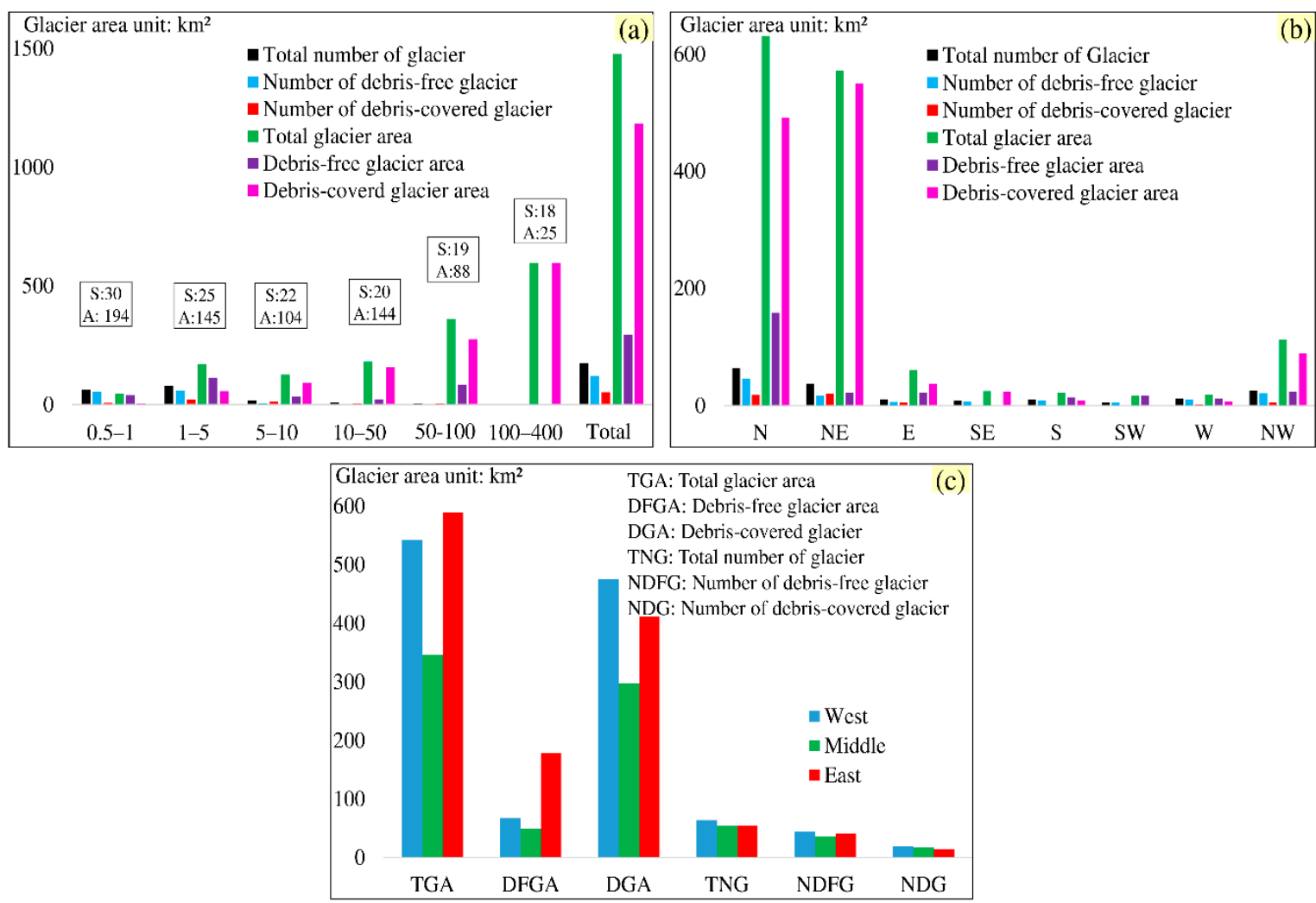

Figure 7. Diagram showing the number, area coverage for different size classes (a), aspect of the glaciers (b) and distribution of glaciers in sub-regions (c). In (a), $\mathrm{S}$ and $\mathrm{A}$ are representing the mean slope and aspect $\left({ }^{\circ}\right)$ value of each size classes. 
Table 4. Topographic parameters of glaciers based on the glacier inventory 2014.

\begin{tabular}{cccccccccc}
\hline \multirow{2}{*}{ Inventory } & \multicolumn{3}{c}{ Overall } & \multicolumn{3}{c}{ Debris-Free Glacier } & \multicolumn{2}{c}{ Debris-Covered Glacier } \\
\cline { 2 - 10 } & Min & Max & Mean & Min & Max & Mean & Min & Max & Mean \\
\hline Min elevation (m) & 3972.0 & 5922.0 & 4960.0 & 4043.0 & 5922.0 & 5083.0 & 3972.0 & 5215.0 & 4676.0 \\
Max elevation (m) & 5560.0 & 7901.0 & 6168.0 & 5581.0 & 7207.0 & 6089.0 & 5560.0 & 7901.0 & 6351.0 \\
Median elevation (m) & 5013.0 & 6058.0 & 5579.0 & 5201.0 & 6058.0 & 5628.0 & 5013.0 & 5794.0 & 5464.0 \\
Slope $\left({ }^{\circ}\right)$ & 15.0 & 43.0 & 26.0 & 15.0 & 43.0 & 27.0 & 15.0 & 36.0 & 24.0 \\
Area $\left(\mathrm{km}^{2}\right)$ & 0.5 & 344.6 & 8.5 & 0.5 & 84.7 & 2.4 & 0.6 & 344.6 & 22.8 \\
Debris cover $\left(\mathrm{km}^{2}\right)$ & & - & & & - & & 0.03 & 41.5 & 2.5 \\
Number of glacier & & 173 & & & 121 & & & 52 & \\
Total Area $\left(\mathrm{km}^{2}\right)$ & & 1478 & & & 295 & & & 1184 & \\
\hline
\end{tabular}

\subsection{Glacier Area Change During Four Decades (1970-2014)}

The results of the multi-temporal glacier inventory indicated that total area of glacier decreased by $22.25 \pm 44.69 \mathrm{~km}^{2}$ during 1970-2014, representing a loss of $1.48 \pm 3.00 \%$ of glacier area (Figures 8 and 9). In detail, results for the different sub-regions showed that glacier area in the middle and eastern parts of study area decreased by $0.82 \pm 3.00 \%$ and $3.26 \pm 3.00 \%$, while the glacier covers in the western part of Shaksgam Valley exhibited very little change $(+0.08 \pm 3.00 \%)$ (Figure 8$)$. However, the estimated area change was less than or similar to the estimated error (Table 3), and thus the glacier area changes of the overall region as well as sub-regions was not significant. In detail, Figure 8 illustrates that except for several glaciers located in the eastern part of study area, which showed significant area decreases compared to the western part of the study site (where the glacier areas mostly increased), most of the glaciers area were stable over this period.

Further analysis of individual glacier area changes by sub-region showed that debris-covered glaciers $\left(>50 \mathrm{~km}^{2}\right)$ were stable in size in all sub-regions. About $60 \%$ of shrinking glacier (area decrease: $-5-\sim 26 \%$ ) in eastern part of study are belonged to small debris-covered glaciers and small debris-free glaciers $\left(<2 \mathrm{~km}^{2}\right)$. On the other hand, small glaciers (most of them $<1 \mathrm{~km}^{2}$ and $\sim 26 \%$ of total glacier in middle part, Figure 8 ) in the south region of middle part of the study area, and medium-sized glaciers (bigger than $2 \mathrm{~km}^{2}$ and less than $11 \mathrm{~km}^{2}$, and $\sim 27 \%$ of total glacier in the western part) in the western parts of Shaksgam Valley significantly increased in area, by $5-28 \%$.

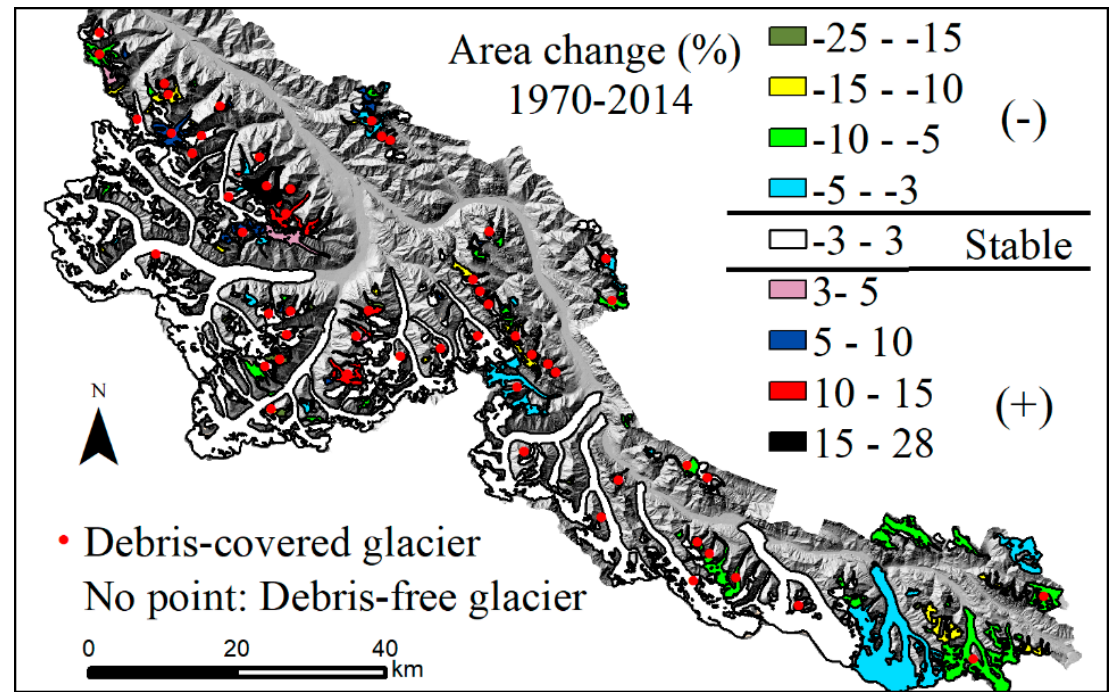

Figure 8. Glacier area change rate during 1970-2014 ((-): decreased in area, (+): increased in area). 


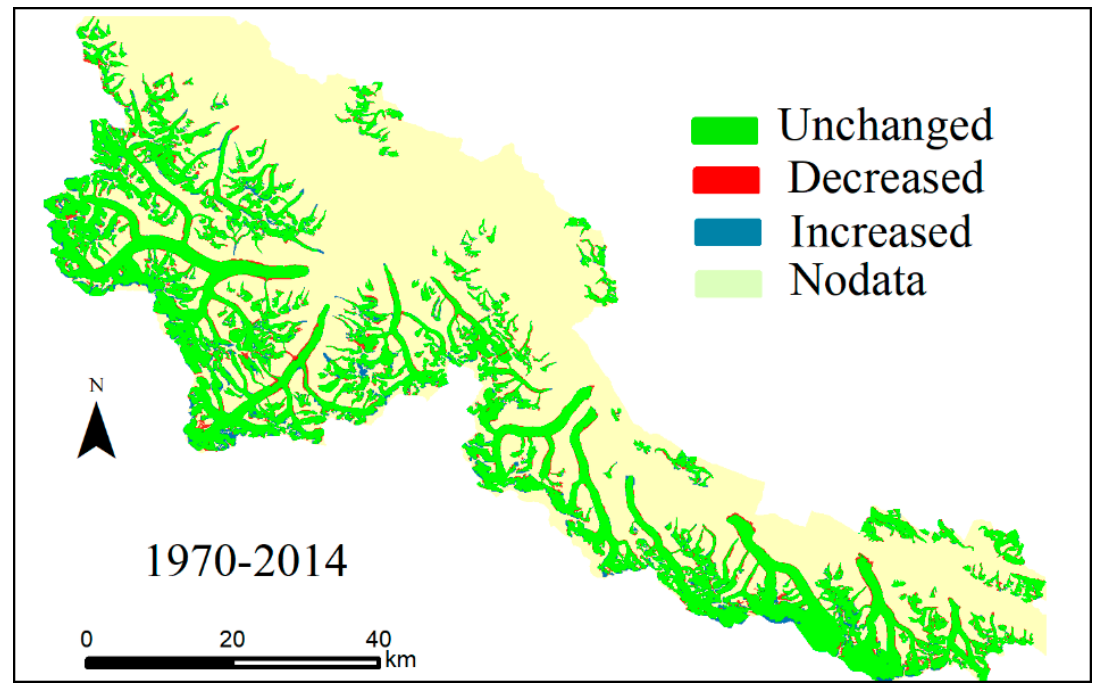

Figure 9. Spatial patterns of glacier are changes during 1970-2014.

\subsection{Decadal Changes in Glacier Area between 1970 and 2014}

The overall results of the glacier inventories for the five different periods are shown in Table 5, Figures 10 and 11.
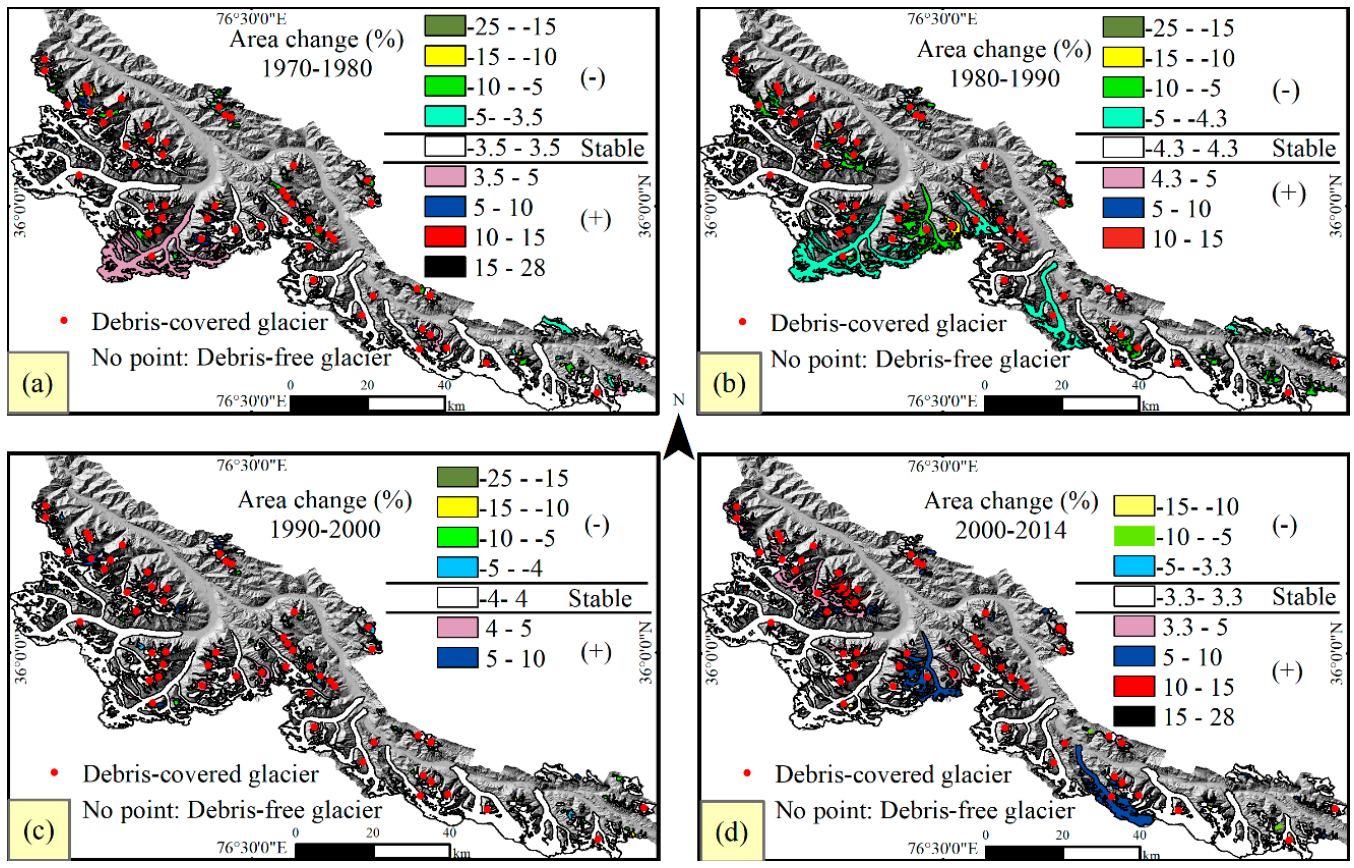

Figure 10. Glacier area change rate during 1970-1980 (a), 1980-1990 (b), 1990-2000 (c) and 2000-2014 (d) periods $((-)$ : decreased in area, $(+)$ : increased in area).

Table 5. Comparison of glacier inventories from this study (glacier area: $\mathrm{km}^{2}$ ).

\begin{tabular}{cccccc}
\hline & Comparison & TGN & Total GA & Mean GA & SDGA \\
\hline \multirow{3}{*}{1970} & Overall & 176 & 1501 & 8.5 & 30.8 \\
& Debris-free glacier & 123 & 329 & 2.7 & 8.2 \\
& Debris-covered glacier & 53 & 1171 & 22.1 & 52.3 \\
\hline
\end{tabular}


Table 5. Cont.

\begin{tabular}{cccccc}
\hline \multirow{2}{*}{1980} & Comparison & TGN & Total GA & Mean GA & SDGA \\
\hline \multirow{3}{*}{1990} & Overall & 177 & 1507 & 8.5 & 30.9 \\
& Debris-free glacier & 123 & 327 & 2.7 & 8.2 \\
& Debris-covered glacier & 54 & 1180 & 21.9 & 52.2 \\
\hline \multirow{3}{*}{2000} & Overall & 173 & 1451 & 8.4 & 30.5 \\
& Debris-free glacier & 120 & 291 & 2.4 & 7.9 \\
& Debris-covered glacier & 53 & 1159 & 21.9 & 51.4 \\
\hline \multirow{3}{*}{2014} & Overall & 173 & 1446 & 8.4 & 30.8 \\
& Debris-free glacier & 120 & 289 & 2.4 & 7.8 \\
& Debris-covered glacier & 53 & 1157 & 21.8 & 51.9 \\
\hline & Oebris-free glacier & 173 & 1478 & 8.5 & 31.4 \\
& Debris-covered glacier & 52 & 295 & 2.4 & 7.7 \\
\hline
\end{tabular}

Note: TGN, total glacier number; GA, glacier area; SDGA, standard deviation of glacier area.

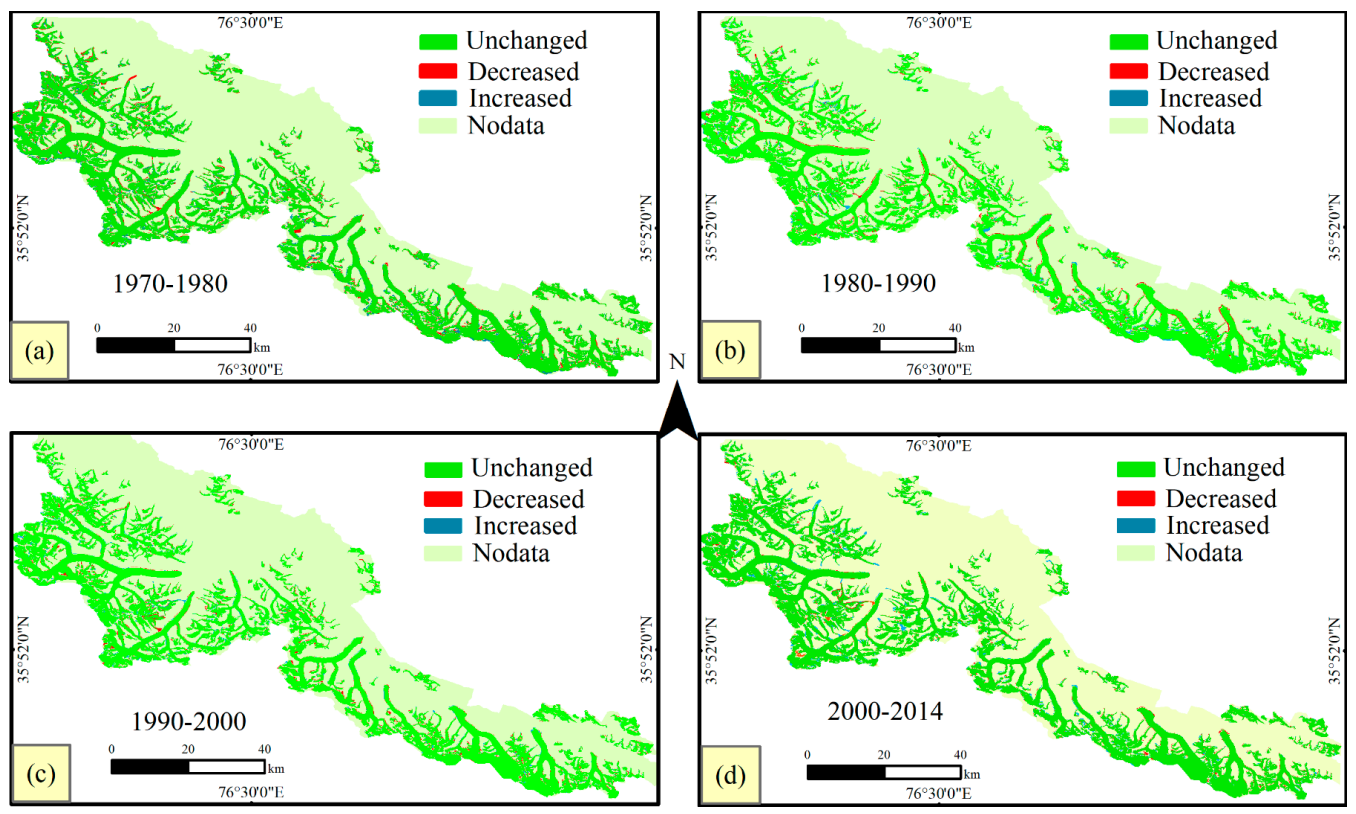

Figure 11. Spatial patterns of glacier area change during 1970-1980 (a), 1980-1990 (b), 1990-2000 (c) and 2000-2014 (d) periods.

The largest glacier area changes $(-3.75 \pm 4.3 \%)$ occurred during the 1980-1990 period, while minor glacier area changes occurred over the 1970-1980 $(+0.44 \pm 3.5 \%)$ and $1990-2000(-0.36 \pm 4.0 \%)$ periods. In the most recent period (2000-2014), the total glacier area increased by $2.3 \pm 3.0 \%$. Decadal glacier area changes overall and in the different sub-regions indicated that no significant glacier area changes occurred. However, further analysis of individual glaciers revealed that most were stable in size during the 1970-1980 period except for small glacier $\left(<2 \mathrm{~km}^{2}\right)$ decreased in area which contain 35\% of glacier in eastern part of study area (Figure 10a) and 1990-2000 periods (Figure 10c). The 1980-1990 period had the highest number of glaciers with significant decreases in area, and these shrinking glaciers were distributed in all sub-regions (Figure 10b). In the 2000-2014 period, the properties of individual glacier area changes showed that most glaciers were stable in size or even increasing in glacier area, with the exception being some very small glaciers that decreased in area (mostly located in the eastern sub-region) (Figure 10d). 
More detailed analysis of individual glacier changes in the different sub-regions between 1970 and 2014 indicated that large numbers of glaciers decreased in area (significant area change) in the eastern part of the study area in almost all periods, whereas glaciers located in the western part of the study area were stable in size (some glaciers even showing increases in area) during 1970 to 2014 (Figure 10). On the other hand, analyzing glacier area changes for the different size classes of glaciers showed that small debris-covered and small debris-free glaciers area decreased in size between 1970 and 2000 (Figure 10). In the case of larger glaciers $\left(>50 \mathrm{~km}^{2}\right)$, they tended to be stable or having slight increases in glacier area from 1970 to 2014 (Figure 10).

\subsection{Glacier Terminus Change}

The distance between the two points representing the minimum elevation of glaciers in different time periods indicates the glacier terminus change. In the entire study area, $32 \%$ of glaciers advanced, $22 \%$ of glaciers were stable, and $46 \%$ of glacier experienced retreat during the 1970-2014 period (Figure 12). However, compared to the advancing glaciers, retreating glaciers tended to be smaller glaciers. Comparing the debris-free and debris-covered glaciers, the number of advancing and retreating debris-free glaciers were more than debris-covered glaciers. Nevertheless, debris-covered glaciers showed a larger total terminus advance (range from 70 to $1400 \mathrm{~m}$ ) and a smaller retreat compared to debris-free glaciers (Figure 12). The terminus changes of glaciers in each sub-region indicated that the middle part was close to equilibrium between glacier advance and retreat (Figure 12b). Retreating glaciers dominated in the eastern part of Shaksgam Valley, and most of the advancing glaciers were located in the western part of the study area (Figure 12c).
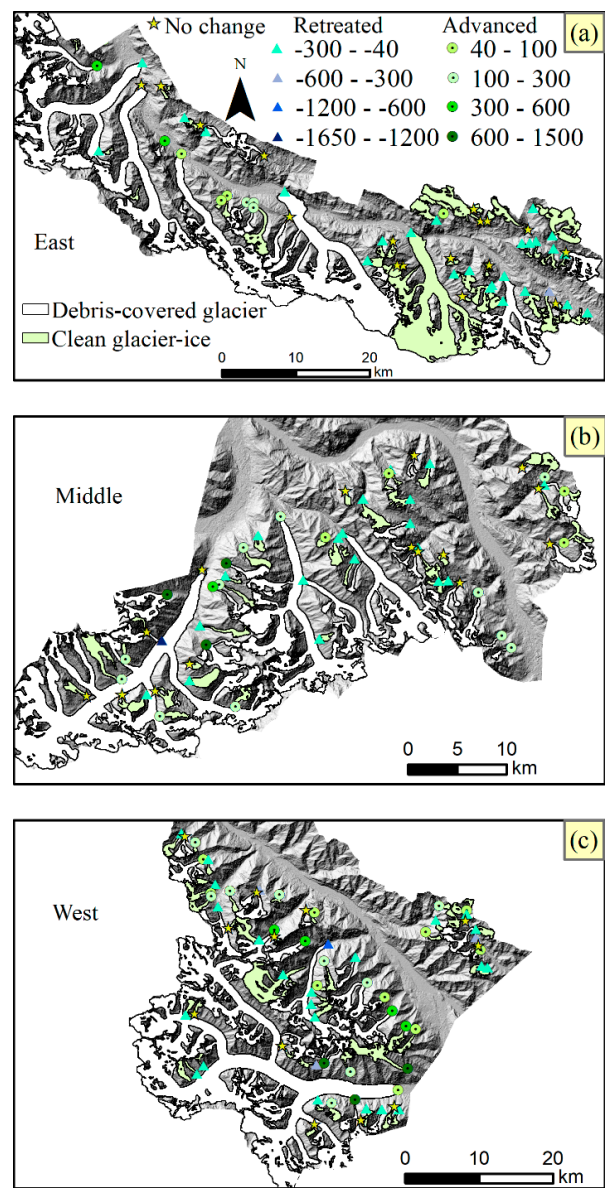

Figure 12. Variations of glaciers terminus position in Eastern (a), Middle (b) and Western (c) sites of study area during the 1970-2014 period (unit: meter). 
For the 1970-1980 and 1990-2000 periods, $47 \%$ and 56\% of glacier terminus were stable, respectively, and $21 \%$ and $18 \%$ of glaciers' terminus advanced (Figures $13 a-c$ and $14 a-c)$. Glacier terminus changes from 1970 to 2014 indicated that $42 \%$ of glaciers (more than half being small debris-free glaciers) retreated during the 1980-1990 (Figure 13d-f) period. Compared to other periods, glacier advance dominated in the recent period (2000-2014) (Figure 14d-f). The number and magnitude of retreating glaciers was greater (in number) and larger (in length) than advancing glaciers during the 1980-1990 period. In detail, retreating of debris-free glaciers occurred in almost all sub-regions and periods (except in the western part during 1980-1990, and the middle and western part during 2000-2014). Debris-free glaciers in the eastern part of the study area showed the largest retreat in all periods. In the case of debris-covered glaciers, the number of retreating debris-covered glaciers was less than for debris-free glaciers, while the total magnitude of advancing debris-covered glaciers was more than for debris-free glaciers. Debris-covered glaciers experienced the most significant advances in the middle ( 3 glaciers advanced more than $1 \mathrm{~km}$ ) and western ( 3 glaciers advanced more than $1 \mathrm{~km}$ ) parts of the Shaksgam Valley during the most recent decade (2000-2014). Most of the advancing glaciers were oriented in the N, NE, and NW directions with a mean slopes of $26^{\circ}(90 \%$ of the glaciers were in the $14-31^{\circ}$ slope range).
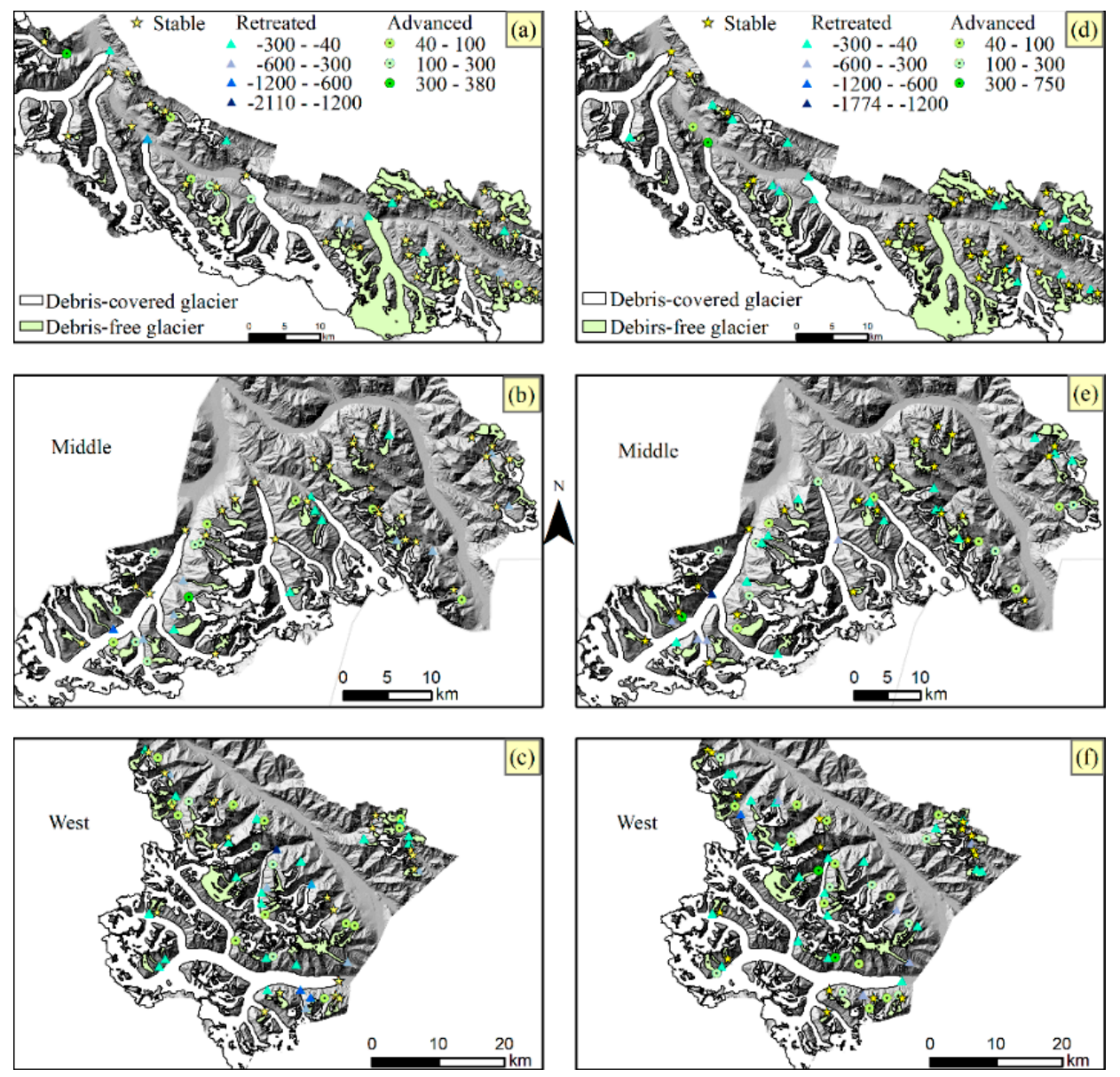

Figure 13. Variations of glaciers terminus position during the 1970-1980 (a-c) and 1980-1990 (d-f) periods (unit: meter). 

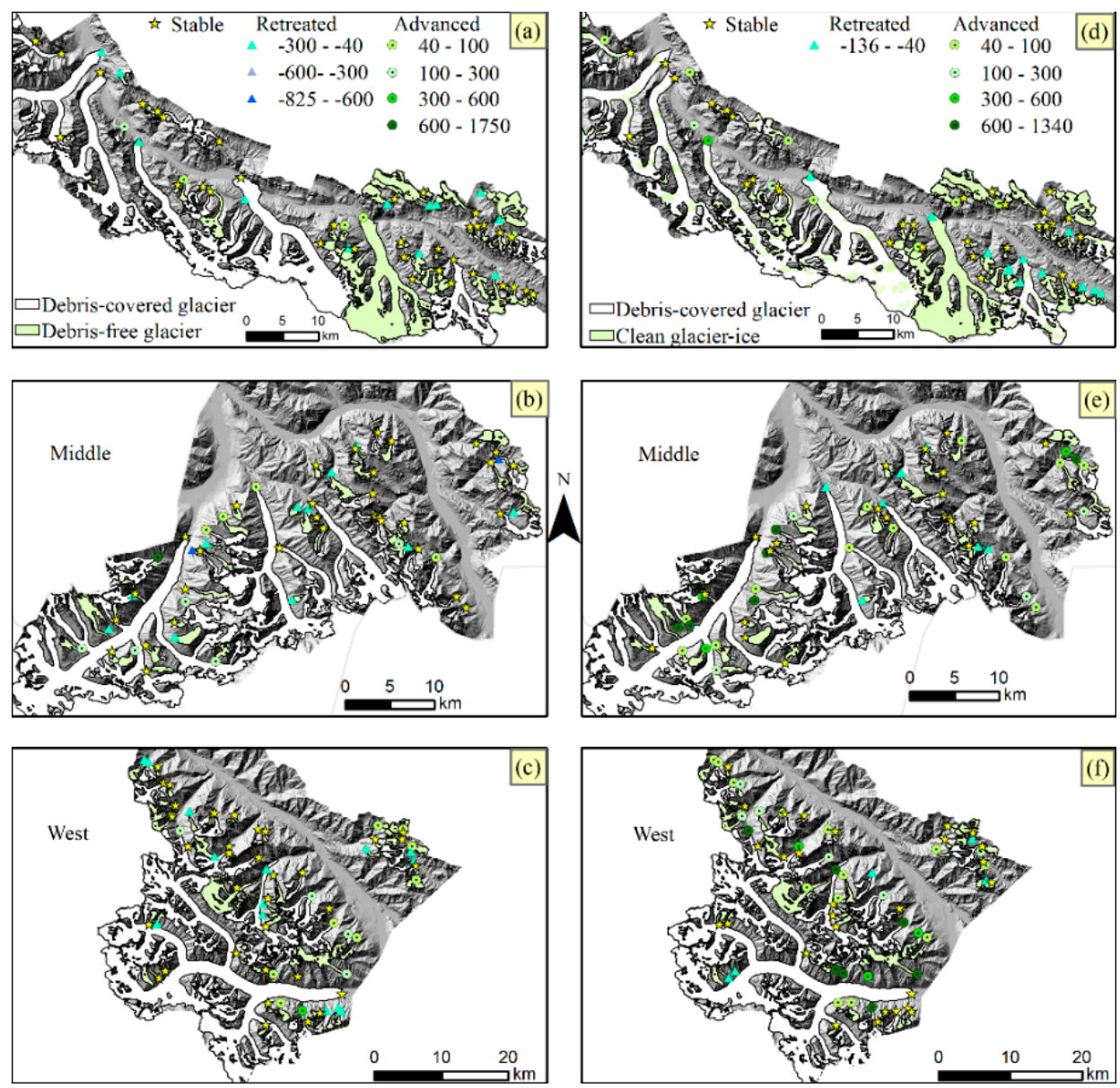

Figure 14. Variations of glaciers terminus position during the 1990-2000 (a-c) and 2000-2014 (d-f) periods (unit: meter).

\section{Discussion}

\subsection{Glacier Change}

In general, overall glacier changes over time in the Shaksgam Valley were quite stable (especially during the 1970-1980 and 1990-2000 periods). Similar to most of the Himalayan glaciers [49], our observation shows that glaciers in Shaksgam Valley retreated in all sub-regions in the 1980-1990 period [50]. Most of the retreating glaciers in this period belonged to the small glacier class (debris-covered and debris-free), and some of them were tributaries of large debris-covered glaciers (i.e., Figure 15b, 1) where the main reason for large debris-covered glacier area decreased which is shown in Figure 10b (in green). The smaller glaciers are, therefore, more sensitive to climate changes due to their location as lower median elevations and smaller ablation regions. Nonetheless, several individual glaciers were still advancing during this period (i.e., Figure 15b, 3). Debris-free glaciers experienced much greater retreats than debris-covered glaciers (except for in the western part of the study area), possibly because the thick debris layer on the debris-covered glaciers, typically concentrated at lower elevations where most of the melting is expected to occur, slowed down the retreats of the debris-covered glacier. Interestingly, the glacier area increased in the most recent period. Several glaciers which belonged to the middle size classes $\left(5-10 \mathrm{~km}^{2}\right)$, mostly located in the western and middle parts of the Shaksgam valley, advanced and merged with large glaciers (i.e., Figure 15b, 2 and Figure 15c, 2). This trend may likely be driven by changes in topography, debris variations (unfortunately no information about debris thickness is available), and the strong effect of regional climatology. 

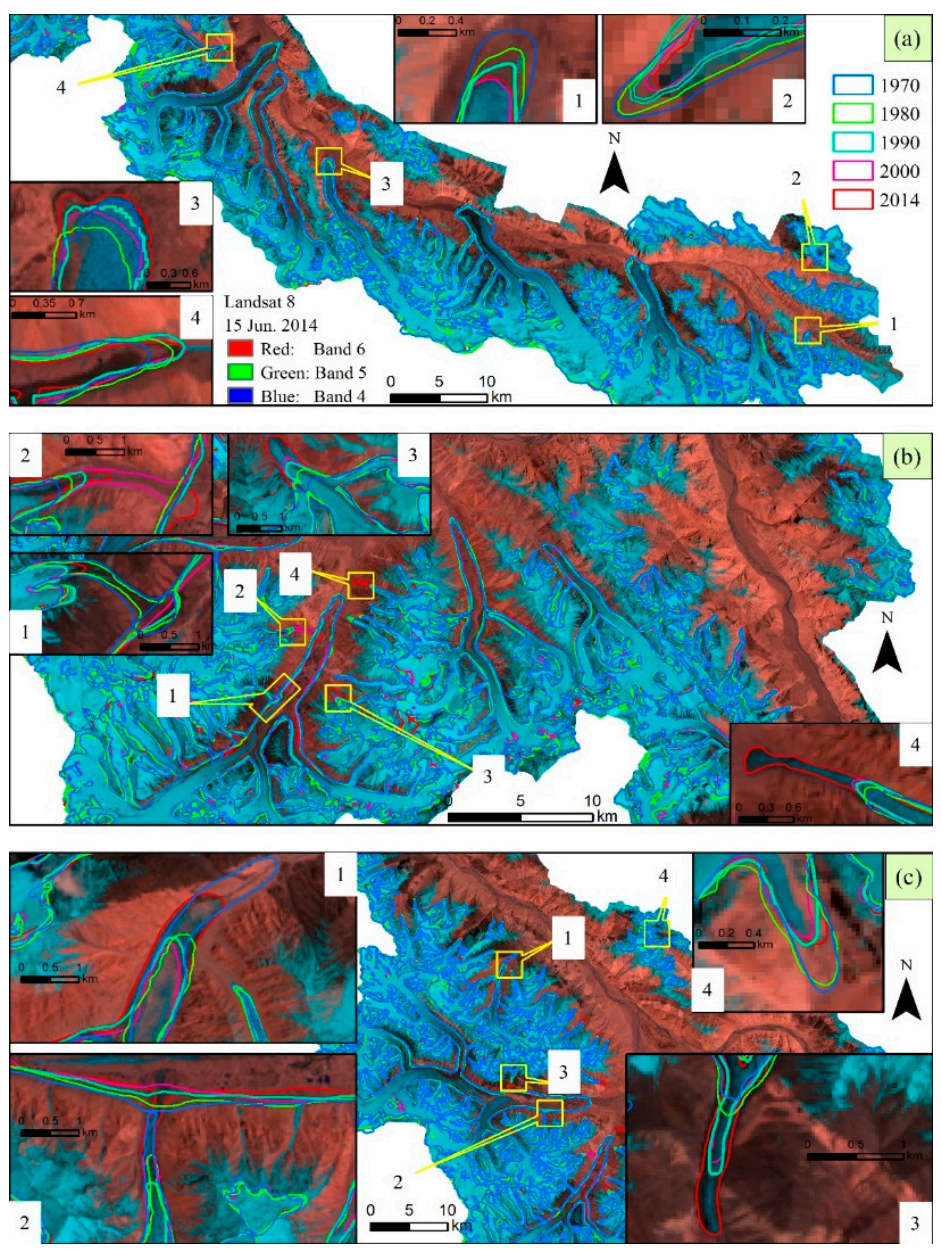

Figure 15. Comparison of glaciers outlines during 1970-2014 in the eastern part (a), middle part (b) and western part of study area (c).

The trend of glacier area changes in this study shows a relatively similar trend to the study by Rankl et al. [17] and other glacier elevation change studies [51,52]. Glacier elevation change studies from Rankl and Braun [51] (Figure 2 in [51]) and Zhou et al. [52] (Figure 4 in [52]) also indicated that glaciers in the western part of Shaksgam Valley have been nearly stable (even though some glaciers were thickened) compared to the other parts of study area. Comparisons of glacier outlines and glacier area (Rankl et al. [17] data was downloaded from https:/ / doi.pangaea.de/10.1594/PANGAEA.873278 and Bhambri et al. [8] data was provided by the first author through a personal communication) from this study and the previous studies were shown in Figure 16. Comparisons of glacier outlines indicated that even using relatively higher resolution of ASTER/Landsat images (15-30 m), precisely detection of debris-covered glaciers boundary by manual digitization (strongly reliant upon spectral information) still faces difficulty when identifying the completely debris-covered glacier termini (Figure 16a). In addition to differences mentioned above (i.e., Figure 16a-c), Bhambri et al. study has overestimated glacier area in this region because the glacier outlines contain the large area of seasonal snow cover (Figure 16d-e). On the other hand, the Rankl et al. study was underestimated the glacier area due to some tributary glaciers were not digitized (Figure 16d). These are the main area differences from previous research compared to this study. 


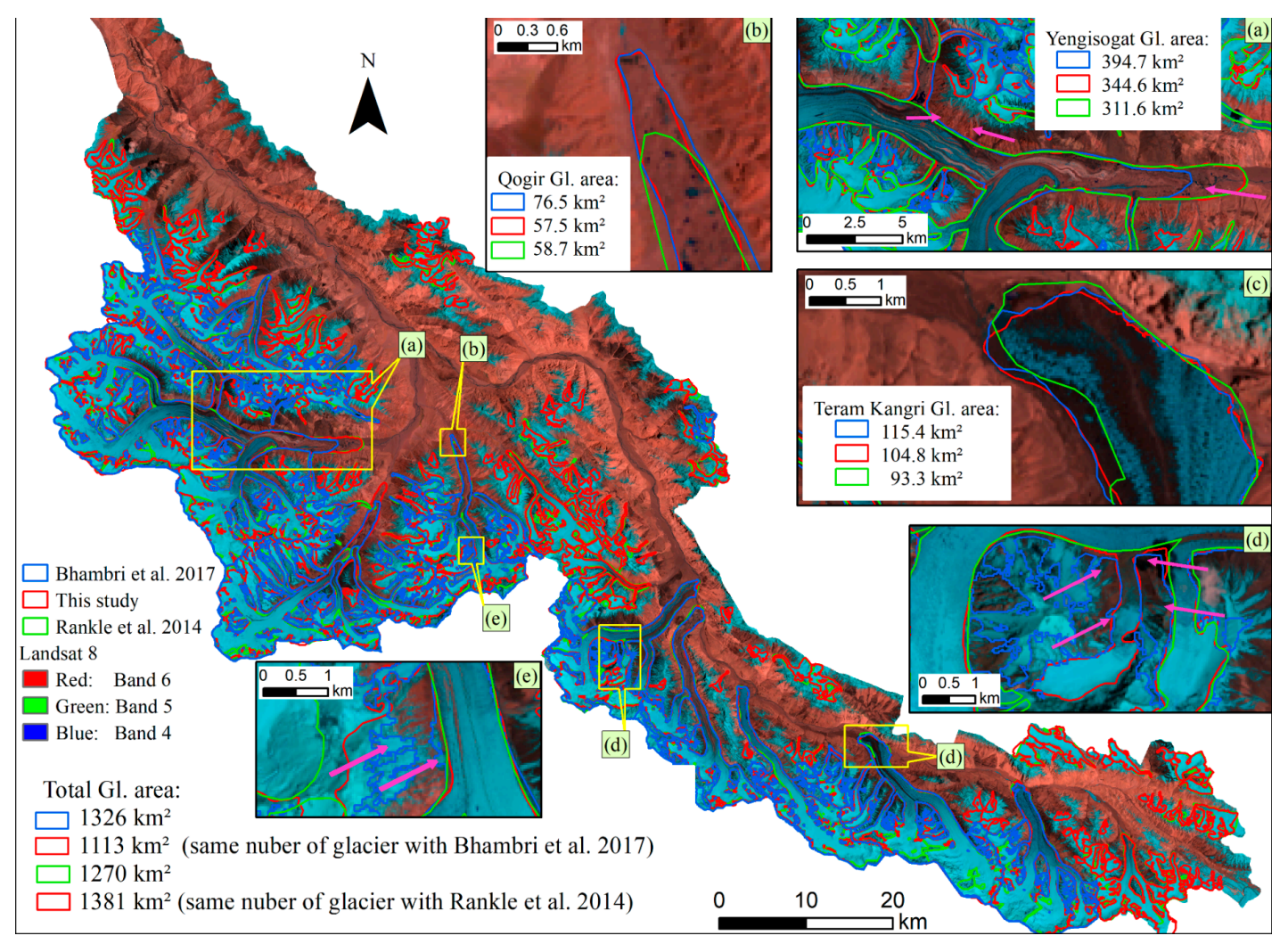

Figure 16. Comparisons of glacier outlines and glacier area based on this study, Rankl et al. study and Bhambri et al. study.

A recently published review study reported that only four area change studies are available from the Karakoram Range covering different regions [9]. However, only one work studied Shaksgam glaciers change, but that study [53] must be regarded with caution because estimation of the glacier area was based on topographic maps (which is source of FCGI)/Landsat images and its uncertainty was not assessed [9]. Therefore, the result of this study provided a comprehensive analysis of glacier area change and detailed multi-temporal glacier inventories compared to the previous study. Moreover, results from our study should have more accurate glacier change estimates than previous work due to (1) the use of high resolution declassified images for the 1970/1980 periods and, (2) the use of semi-automatic glacier mapping methods based on the spectral, thermal and landscape properties of glaciers for more recent periods. However, our study excluded very small glaciers $\left(<0.5 \mathrm{~km}^{2}\right)$ because those glaciers present larger uncertainty when delineated using Landsat images [40]. Finally, the multi-temporal glacier outlines (including topographic parameters) of the Shaksgam Valley will be published with this paper and will be made freely available.

\subsection{Glacier Area Change with Glacier Topographic Parameters}

Glacier changes can be strongly influenced by topographic characteristic and climate variations. Thus, multi-regression analysis was applied to examine the relationship between the magnitude of glacier change (percentage of glacier area change bigger than $5 \%$ ) with various topographic parameters.

Regression analysis results are illustrated in Tables 6 and 7. According to the results, the $p$ value for all variables were found to be not significant at $<0.001$, while the $R^{2}$ value of the regression value was also relatively low: $R^{2}=0.087$ ( $R^{2}=0.016$ for debris cover). On the other hand, the result of regression analysis of glacier advance/retreat also showed a low $\mathrm{R}^{2}$ and no significant $p$ values. Overall, the regression results indicate that the topographic parameters were not the main driver of glacier change in the Shaksgam Valley. 
Table 6. Regression between glacier area change and glacier parameters (84 observations) and regression between glacier area change and debris-cover (52 observations).

\begin{tabular}{cccc}
\hline Regression & R Square & Coefficient & $p$ Value \\
\hline Glacier area & & 0.042 & 0.590 \\
Min elevation & & -0.001 & 0.817 \\
Max elevation & \multirow{2}{*}{0.087} & 0.001 & 0.898 \\
Median elevation & & 0.002 & 0.684 \\
Slope & & -0.134 & 0.196 \\
Aspect & & -0.003 & 0.929 \\
\hline Debris-cover & 0.016 & 0.101 & 0.110 \\
\hline
\end{tabular}

Table 7. Regression analysis between glacier terminus advance (56 observations, left) and retreat (77 observations, right) with glacier parameters.

\begin{tabular}{ccccccc}
\hline Regression & R Square & Coefficient & $p$ Value & R Square & Coefficient & $p$ Value \\
\hline Glacier area & & -2.417 & 0.050 & & -2.103 & 0.414 \\
Min elevation & & -0.401 & 0.155 & & -0.725 & 2.542 \\
Max elevation & 0.172 & -0.206 & 0.304 & 0.264 & -0.177 & 0.211 \\
Median elevation & & 0.296 & 0.462 & & 0.465 & 0.058 \\
Slope & & -2.373 & 0.796 & & -6.110 & 0.252 \\
Aspect & & -0.202 & 0.586 & & -0.212 & 0.303 \\
\hline
\end{tabular}

\subsection{Glacier Area Change with Climate Considerations}

Climatic factors such as cloud cover, precipitation, and temperature may have also caused glacier changes in Shaksgam Valley. In general, incoming short-wave radiation is the major source of energy for glacier change [54]. However, cloud cover may alter the amount of incoming short-wave radiation as well as air temperatures [54]. The percentage of cloud cover in the Shaksgam Valley was obtained from the online Global 1-km Cloud Cover observation database [37]. From this dataset, we found that the mean annual percent cloud cover and mean monthly (May-October) percent cloud cover were higher in the western part of study area compared to the other regions (Figure 17). Furthermore, most of the areas with frequent cloud cover were located on the accumulation zones of the glacier. Previous studies based on the weather observation stations and global meteorological reanalysis data, also reported an increase of cloudiness in the Karakoram region [54,55]. Moreover, the previous research also reported that increases in cloudiness led to increases in precipitation, decreases in incoming solar radiation, and a reduction in the air temperatures [54,55].

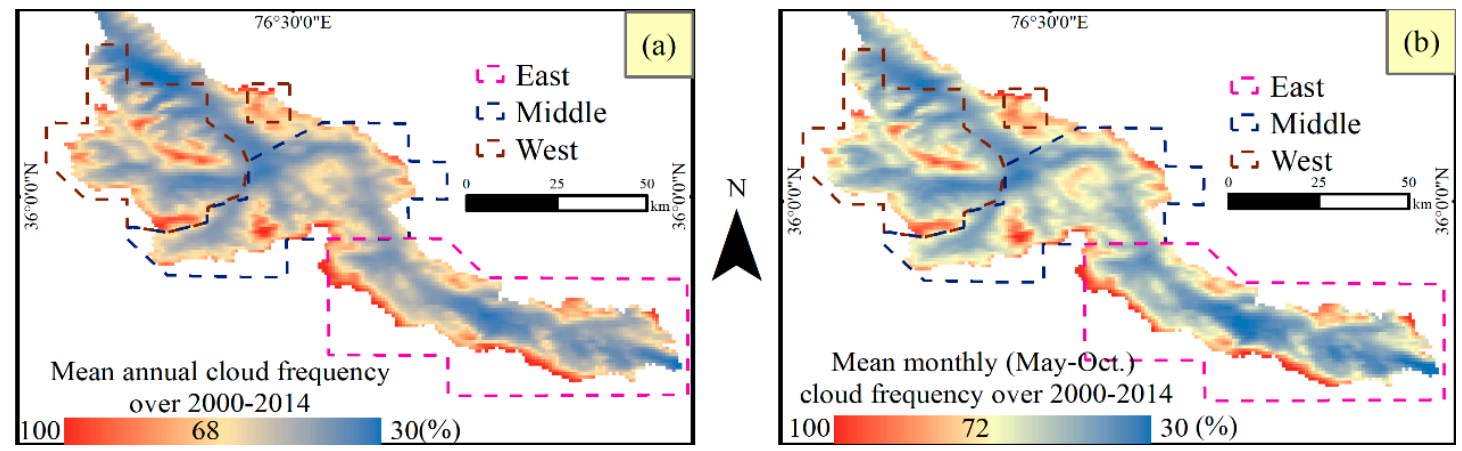

Figure 17. Mean annual (a) and mean monthly (b) cloud cover fraction of Shaksgam Valley derived from Global 1-km Cloud Cover observation database [35].

Moreover, variation of cloudiness is concurrent with temperature and precipitation change data derived from the CFMD dataset during 1979-2015 (Figures 17 and 18). Further analysis of the 
spatial distribution of mean annual temperature and precipitation from CFMD (Figure 18) indicated that lower temperature and higher precipitation were dominated in the western part and south of the middle part of the Shaksgam Valley compared to the eastern part. Spatial variations of mean annual precipitation also revealed increased precipitation in the eastern part of the study area in the recent period (Figure 18h). Similar results were reported based on observation stations [56] (such as Tashkorgan, which is the nearest meteorological station to the Shaksgam Valley, see Figure 1) and satellite-based estimations (TRMM) [57]. Based on the meteorological stations, Yaning et al. concluded that annual mean temperature slightly increased during 1960-2010 [56]. Moreover, the decadal mean and decadal summer mean temperature even showed decreases in the recent decade. On the other hand, the result of precipitation change derived from observations as well as satellite data based showed a steady increase from 1960-2010 [56-58]. Precipitation estimates from satellites also indicated that the amount of precipitation in the glacial region had been underestimated [57]. Bashir et al. further confirmed that similar in precipitation and temperature were observed in the upper Indus basin located closely to the study area [55].
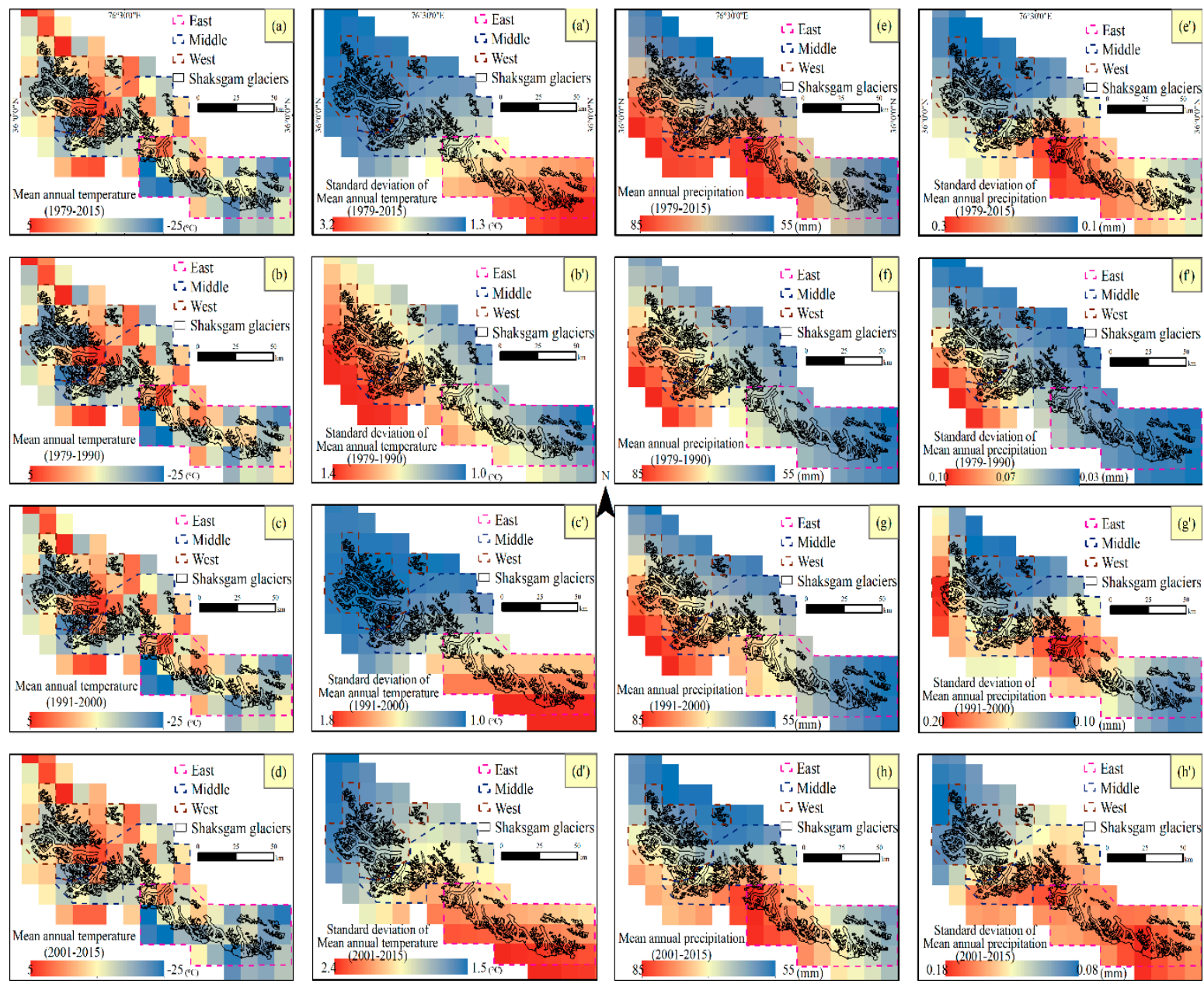

Figure 18. Mean annual temperature $(\mathbf{a}-\mathbf{d})$, standard deviation of mean annual temperature $\left(\mathbf{a}^{\prime}-\mathbf{d}^{\prime}\right)$, mean annual precipitation $(\mathbf{e}-\mathbf{h})$ and standard deviation of mean annual precipitation $\left(\mathbf{e}^{\prime}-\mathbf{h}^{\prime}\right)$ in the Shaksgam Valley during 1979-2015.

Results revealed that most of the shrinking glaciers are small glaciers, and small glaciers are more sensitive to the climatic variations than larger glaciers [59-61], therefore, climate variations can explain the glacier area decreases dominant in the eastern part of the Shaksgam valley during the 1970 to 2000 period (Figures 8, 10 and 18). On the other hand, long-term higher precipitation and lower temperature 
interpreted the climate variations played an important role in glacier advances in the western part of study area [62]. Thus, the glacier changes in Shaksgam Valley probably have a strong relationship with specific regional climate variations (combination of temperature and precipitation).

\subsection{Limitations of the Study}

There are several limitations in the proposed method used in this study, which can be summarized as:

1. Experience from transferability of this method to other regions $[29,63]$ indicated that the [TIR/(NIR/SWIR)] band ratio image misclassified vegetation cover near the glacier tongue as supraglacial debris, particularly in the case of debris-covered glacier covered by vegetation.

2. Rock glaciers and ice-cored moraines are not possible to detect by the proposed method due to their much smaller size and overall area being entirely covered by rocky materials compared to the debris-covered glacier. Importantly, the thermal properties of rock glaciers and ice-cored moraines are undetectable because of a very thick deposit layer [64].

3. Small hanging debris-covered glaciers had the highest uncertainty in glacier delineation mainly due to the limited image resolution. Therefore, manual editing steps are still required for small debris-covered glaciers and river channels connected with a glacier tongue and isolated areas that are outside the main body of the glacier.

\section{Conclusions}

This research takes advantage of various freely-available remote sensing data sets to generate multi-temporal glacier inventories (1970, 1980, 1990, 2000 and 2014) of the Shaksgam Valley located in the northern slope of the Chinese Karakoram region. As of 2014, 173 glaciers $\left(>0.5 \mathrm{~km}^{2}\right)$ (including 121 debris-free glaciers), covering an area of $1478 \pm 34 \mathrm{~km}^{2}$ (debris-free glacier area: $295 \pm 7 \mathrm{~km}^{2}$ ) were inventoried. About $10 \%$ of the total glacier area was debris-covered. Overall, the total glacier area change was stable from 1970-2014. Nonetheless, individual glacier changes showed significant variability. Glaciers in the Shaksgam Valley still showed significant advances of terminus positions, especially in the recent decade, compared to the worldwide trend of glacier retreat. Notably, glaciers located in the western part of the study area experienced significant levels of increase in glacier area. The results from a regression analysis indicated that glacier changes in the Shaksgam Valley were not strongly related to the local topography, and were more likely due to local climate variations (e.g., changes in cloud cover, precipitation, and air temperatures). Unfortunately, it was not possible to investigate how the debris thickness of glaciers affected the rates of glacier change in this region due to the lack of debris thickness data. However, we did find clear evidence that the variation of small glacier-ice extent was more sensitive to the climate variations compared to the larger glaciers. Finally, because (multi-temporal) glacier inventory data is a standard requirement for various climatological and hydrological studies, the glacier inventory data from this research has been made freely available as supplemental material to this paper.

Supplementary Materials: The following are available online at http:/ /www.mdpi.com/2072-4292/10/8/1166/ s1.

Author Contributions: H.A. conceived, designed and performed the research, M.U. did the ASTER DEM generation. B.A.J. and J.-F.V. reviewed the manuscript and gave valuable suggestions for improving the manuscript. A.K. and Y.H. advised the research. H.A. wrote the paper.

Funding: This work was financially supported by the Funding Program for the Global Environmental Research Fund (S-14) of the Ministry of the Environment, Japan.

Acknowledgments: We would like to thank NASA/USGS, METI of Japan/NASA for providing the Declassified images, Landsat data, SRTM and ASTER GDEM version two Data. We thank the Japan Space Systems Earth Remote Sensing Division and the JAXA Earth Observation Research Center for providing the ASTER images and AW3D30. The CFMD forcing dataset used in this study was developed by the Data Assimilation and Modeling Center for Tibetan Multi-spheres, Institute of Tibetan Plateau Research, Chinese Academy of Sciences. 
We especially thank the ESA and Nagoya University for providing the Glaciers_cci and GAMDAM Glacier Inventory data for validation of our work. Also, we thank Bhambri R. for providing the glacier inventory data. We would like to thank the anonymous reviewers and the editor for their very constructive and helpful comments.

Conflicts of Interest: The authors declare no conflict of interest.

\section{References}

1. Vaughan, D.G.; Comiso, J.C.; Allison, I.; Carrasco, J.; Kaser, G.; Kwok, R.; Mote, P.; Murray, T.; Paul, F.; Ren, J.; et al. Observations: Cryosphere; Cambridge University Press: Cambridge, UK; New York, NY, USA, 2013; pp. 317-382.

2. Haeberli, W.; Hoelzle, M.; Paul, F.; Zemp, M. Integrated monitoring of mountain glaciers as key indicators of global climate change: The European Alps. Ann. Glaciol. 2017, 46, 150-160. [CrossRef]

3. Pieczonka, T.; Bolch, T.; Wei, J.F.; Liu, S.Y. Heterogeneous mass loss of glaciers in the Aksu-Tarim Catchment (Central Tien Shan) revealed by 1976 KH-9 Hexagon and 2009 SPOT-5 stereo imagery. Remote Sens. Environ. 2013, 130, 233-244. [CrossRef]

4. Zhang, X.S. Investigation of glacier bursts of the Yarkant river in Xinjiang, China. Ann. Glaciol. 2017, 16, 135-139.

5. Round, V.; Leinss, S.; Huss, M.; Haemmig, C.; Hajnsek, I. Surge dynamics and lake outbursts of Kyagar glacier, Karakoram. Cryosphere 2017, 11, 723-739. [CrossRef]

6. Hewitt, K.; Liu, J.S. Ice-dammed lakes and outburst floods, Karakoram Himalaya: Historical perspectives on emerging threats. Phys. Geogr. 2010, 31, 528-551. [CrossRef]

7. Kääb, A.; Treichler, D.; Nuth, C.; Berthier, E. Brief communication: Contending estimates of 2003-2008 glacier mass balance over the Pamir-Karakoram-Himalaya. Cryosphere 2015, 9, 557-564. [CrossRef]

8. Bhambri, R.; Hewitt, K.; Kawishwar, P.; Pratap, B. Surge-type and surge-modified glaciers in the Karakoram. Sci. Rep. 2017. [CrossRef] [PubMed]

9. Azam, M.F.; Wagnon, P.; Berthier, E.; Vincent, C.; Fujita, K.; Kargel, J.S. Review of the status and mass changes of Himalayan-Karakoram glaciers. J. Glaciol. 2018, 64, 61-74. [CrossRef]

10. Koboltschnig, G.R.; Schoner, W.; Zappa, M.; Kroisleitner, C.; Holzmann, H.R. Runoff modelling of the glacierized Alpine Upper Salzach basin (Austria): Multi-criteria result validation. Hydrol. Process. 2008, 22, 3950-3964. [CrossRef]

11. Hirabayashi, Y.; Doll, P.; Kanae, S. Global-scale modeling of glacier mass balances for water resources assessments: Glacier mass changes between 1948 and 2006. J. Hydrol. 2010, 390, 245-256. [CrossRef]

12. Pfeffer, W.T.; Arendt, A.A.; Bliss, A.; Bolch, T.; Cogley, J.G.; Gardner, A.S.; Hagen, J.O.; Hock, R.; Kaser, G.; Kienholz, C.; et al. The Randolph Glacier Inventory: A globally complete inventory of glaciers. J. Glaciol. 2014, 60, 537-552. [CrossRef]

13. Shi, Y.; Liu, S.; Ye, B.; Liu, C.; Wang, Z. Concise Glacier Inventory of China; Shanghai Popular Science Press: Shanghai, China, 2008.

14. Guo, W.Q.; Liu, S.Y.; Xu, L.; Wu, L.Z.; Shangguan, D.H.; Yao, X.J.; Wei, J.F.; Bao, W.J.; Yu, P.C.; Liu, Q.; et al. The second Chinese glacier inventory: Data, methods and results. J. Glaciol. 2015, 61, 357-372. [CrossRef]

15. Glaciers_cci (2015): Climate Research Data Package (CRDP) Technical Document. Available online: http: / / www.esa-glaciers-cci.org/ (accessed on 19 March 2018).

16. Nuimura, T.; Sakai, A.; Taniguchi, K.; Nagai, H.; Lamsal, D.; Tsutaki, S.; Kozawa, A.; Hoshina, Y.; Takenaka, S.; Omiya, S.; et al. The GAMDAM glacier inventory: A quality-controlled inventory of Asian glaciers. Cryosphere 2015, 9, 849-864. [CrossRef]

17. Rankl, M.; Kienholz, C.; Braun, M. Glacier changes in the Karakoram region mapped by multimission Satellite imagery. Cryosphere 2014, 8, 977-989. [CrossRef]

18. Bolch, T.; Yao, T.; Kang, S.; Buchroithner, M.F.; Scherer, D.; Maussion, F.; Huintjes, E.; Schneider, C. A glacier inventory for the western Nyainqentanglha Range and the Nam co basin, Tibet, and glacier changes 1976-2009. Cryosphere 2010, 4, 419-433. [CrossRef]

19. Racoviteanu, A.E.; Arnaud, Y.; Williams, M.W.; Manley, W.F. Spatial patterns in glacier characteristics and area changes from 1962 to 2006 in the Kanchenjunga-sikkim area, eastern Himalaya. Cryosphere 2015, 9, 505-523. [CrossRef]

20. Kuhle, M. The maximum ice age glaciation between the Karakorum main ridge (K2) and the Tarim basin and its influence on global energy balance. J. Mt. Sci. 2005, 2, 5-22. [CrossRef] 
21. Bookhagen, B.; Burbank, D.W. Toward a complete Himalayan hydrological budget: Spatiotemporal distribution of snowmelt and rainfall and their impact on river discharge. J. Geophys. Res. Earth Surf. 2010, 115. [CrossRef]

22. Jiang, Z.L.; Liu, S.Y.; Peters, J.; Lin, J.; Long, S.C.; Han, Y.S.; Wang, X. Analyzing Yengisogat Glacier surface velocities with ALOS PALSAR data feature tracking, Karakoram, China. Environ. Earth Sci. 2012, 67, 1033-1043. [CrossRef]

23. Sinha, R.; Ravindra, R. Earth System Processes and Disaster Management; Sinha, R., Ravindra, R., Eds.; Springer: Berlin/Heidelberg, Germany, 2012.

24. Copland, L.; Sylvestre, T.; Bishop, M.P.; Shroder, J.F.; Seong, Y.B.; Owen, L.A.; Bush, A.; Kamp, U. Expanded and recently increased glacier surging in the Karakoram. Arct. Antarct. Alp. Res. 2011, 43, 503-516. [CrossRef]

25. Bhambri, R.; Bolch, T.; Kawishwar, P.; Dobhal, D.P.; Srivastava, D.; Pratap, B. Heterogeneity in glacier response in the upper Shyok valley, northeast Karakoram. Cryosphere 2013, 7, 1385-1398. [CrossRef]

26. Sohn, H.G.; Kim, G.H.; Yom, J.H. Mathematical modelling of historical reconnaissance CORONA KH-4B imagery. Photogramm. Rec. 2004, 19, 51-65. [CrossRef]

27. Surazakov, A.; Aizen, V. Positional accuracy evaluation of declassified HEXAGON KH-9 mapping camera imagery. Photogramm. Eng. Remote Sens. 2010, 76, 603-608. [CrossRef]

28. Holzer, N.; Vijay, S.; Yao, T.; Xu, B.; Buchroithner, M.; Bolch, T. Four decades of glacier variations at Muztagh Ata (eastern Pamir): A multi-sensor study including HEXAGON KH-9 and Pleiades data. Cryosphere 2015, 9, 2071-2088. [CrossRef]

29. Alifu, H.; Tateishi, R.; Johnson, B. A new band ratio technique for mapping debris-covered glaciers using Landsat imagery and a digital elevation model. Int. J. Remote Sens. 2015, 36, 2063-2075. [CrossRef]

30. Alifu, H.; Johnson, B.A.; Tateishi, R. Delineation of debris-covered glaciers based on a combination of geomorphometric parameters and a TIR/NIR/SWIR band ratio. IEEE J. Sel. Top. Appl. Earth Obs. Remote Sens. 2016, 9, 781-792. [CrossRef]

31. Haeberli, W.; Hoelzle, M. Application of inventory data for estimating characteristics of and regional climate-change effects on mountain glaciers: A pilot study with the European Alps. Ann. Glaciol. 1995, 21, 206-212. [CrossRef]

32. Racoviteanu, A.E.; Arnaud, Y.; Williams, M.W.; Ordonez, J. Decadal changes in glacier parameters in the cordillera blanca, peru, derived from remote sensing. J. Glaciol. 2008, 54, 499-510. [CrossRef]

33. Paul, F.; Frey, H.; Le Bris, R. A new glacier inventory for the European Alps from Landsat TM scenes of 2003: Challenges and results. Ann. Glaciol. 2011, 52, 144-152. [CrossRef]

34. Tadono, T.; Takaku, J.; Tsutsui, K.; Oda, F.; Nagai, H.; IEEE. Status of “ALOS World 3D (AW3D)” Global DSM generation. In Proceedings of the 2015 IEEE International Geoscience and Remote Sensing Symposium, Milan, Italy, 26-31 July 2015; pp. 3822-3825.

35. Takaku, J.; Tadono, T.; Tsutsui, K.; Ichikawa, M. Validation of 'AW3D' Global DSM generated from ALOS PRISM. Ann. Photogramm. Remote Sens. Spat. Inf. Sci. 2016, 3, 25-31.

36. Tadono, T.; Nagai, H.; Ishida, H.; Oda, F.; Naito, S.; Minakawa, K.; Iwamoto, H. Generation of the 30 m-mesh global digital surface model by alos prism. Int. Arch. Photogramm. Remote Sens. Spat. Inf. Sci. 2016, 41, 157-162. [CrossRef]

37. Wilson, A.M.; Jetz, W. Remotely sensed high-resolution global cloud dynamics for predicting ecosystem and biodiversity distributions. PLoS Biol. 2016, 14, e1002415. [CrossRef] [PubMed]

38. Chen, Y.Y.; Yang, K.; He, J.; Qin, J.; Shi, J.C.; Du, J.Y.; He, Q. Improving land surface temperature modeling for dry land of China. J. Geophys. Res. Atmos. 2011, 116. [CrossRef]

39. He, J.; Yang, K. China Meteorological Forcing Dataset. Cold and Arid Regions Science Data Center at Lanzhou. Available online: http:/ / westdc.westgis.ac.cn/data/7a35329c-c53f-4267-aa07-e0037d913a21 (accessed on 12 March 2018).

40. Müller, F.; Caflisch, T.; Müller, G. Instructions for Compilation and Assemblage of Data for a World Glacier Inventory. Available online: https://wgms.ch/downloads/Mueller_etal_UNESCO_1977.pdf (accessed on 12 June 2018).

41. Fischer, M.; Huss, M.; Barboux, C.; Hoelzle, M. The New Swiss Glacier Inventory sgi2010: Relevance of Using High-resolution Source Data in Areas Dominated by Very Small Glaciers. Arct. Antarct. Alp. Res. 2014, 46, 933-945. [CrossRef] 
42. Toutin, T. Aster DEMs for geomatic and geoscientific applications: A review. Int. J. Remote Sens. 2008, 29, 1855-1875. [CrossRef]

43. Paul, F.; Barry, R.G.; Cogley, J.G.; Frey, H.; Haeberli, W.; Ohmura, A.; Ommanney, C.S.L.; Raup, B.; Rivera, A.; Zemp, M. Recommendations for the compilation of glacier inventory data from digital sources. Ann. Glaciol. 2009, 50, 119-126. [CrossRef]

44. RGI Consortium. Randolph Glacier Inventory-A Dataset of Global Glacier Outlines: Version 6.0. Available online: http:/ / www.glims.org/RGI/randolph60.html (accessed on 28 July 2017).

45. Bolch, T.; Menounos, B.; Wheate, R. Landsat-based inventory of glaciers in western Canada, 1985-2005. Remote Sens. Environ. 2010, 114, 127-137. [CrossRef]

46. Tennant, C.; Menounos, B.; Wheate, R.; Clague, J.J. Area change of glaciers in the Canadian Rocky Mountains, 1919 to 2006. Cryosphere 2012, 6, 1541-1552. [CrossRef]

47. Hall, D.K.; Bayr, K.J.; Schoner, W.; Bindschadler, R.A.; Chien, J.Y.L. Consideration of the errors inherent in mapping historical glacier positions in Austria from the ground and space (1893-2001). Remote Sens. Environ. 2003, 86, 566-577. [CrossRef]

48. Chand, P.; Sharma, M.C. Glacier changes in the Ravi basin, North-Western Himalaya (India) during the last four decades (1971-2010/13). Glob. Planet. Chang. 2015, 135, 133-147. [CrossRef]

49. Bolch, T.; Kulkarni, A.; Kaab, A.; Huggel, C.; Paul, F.; Cogley, J.G.; Frey, H.; Kargel, J.S.; Fujita, K.; Scheel, M.; et al. The state and fate of Himalayan glaciers. Science 2012, 336, 310-314. [CrossRef] [PubMed]

50. Hewitt, K. The karakoram anomaly? Glacier expansion and the 'elevation effect', Karakoram Himalaya. Mt. Res. Dev. 2005, 25, 332-340. [CrossRef]

51. Rankl, M.; Braun, M. Glacier elevation and mass changes over the central Karakoram region estimated from TanDEM-X and SRTM/X-SAR digital elevation models. Ann. Glaciol. 2016, 57, 273-281. [CrossRef]

52. Zhou, Y.; Li, Z.; Li, J. Slight glacier mass loss in the Karakoram region during the 1970s to 2000 revealed by KH-9 images and SRTM DEM. J. Glaciol. 2017, 63, 331-342. [CrossRef]

53. Liu, S.; Ding, Y.; Shangguan, D.; Zhang, Y.; Li, J.; Han, H.; Wang, J.; Xie, C. Glacier retreat as a result of climate warming and increased precipitation in the Tarim river basin, northwest China. Ann. Glaciol. 2006, 43, 91-96. [CrossRef]

54. Forsythe, N.; Hardy, A.J.; Fowler, H.J.; Blenkinsop, S.; Kilsby, C.G.; Archer, D.R.; Hashmi, M.Z. A Detailed Cloud Fraction Climatology of the Upper Indus Basin and Its Implications for Near-Surface Air Temperature. J. Clim. 2015, 28, 3537-3556. [CrossRef]

55. Bashir, F.; Zeng, X.B.; Gupta, H.; Hazenberg, P. A hydrometeorological perspective on the Karakoram anomaly using unique valley-based synoptic weather observations. Geophys. Res. Lett. 2017, 44, 10470-10478. [CrossRef]

56. Chen, Y.N.; Xu, C.C.; Hao, X.M.; Li, W.H.; Chen, Y.P.; Zhu, C.G.; Ye, Z.X. Fifty-year climate change and its effect on annual runoff in the Tarim river basin, China. Quat. Int. 2009, 208, 53-61.

57. Wang, Q.Y.; Yi, S.; Sun, W.K. P Precipitation-driven glacier changes in the Pamir and Hindu Kush mountains. Geophys. Res. Lett. 2017, 44, 2817-2824. [CrossRef]

58. Li, B.F.; Chen, Y.N.; Shi, X.; Chen, Z.S.; Li, W.H. Temperature and precipitation changes in different environments in the arid region of northwest China. Theor. Appl. Climatol. 2013, 112, 589-596. [CrossRef]

59. Reid, H. The mechanics of glaciers. J. Geol. 1896, 4, 912-928. [CrossRef]

60. Salinger, J.; Chinn, T.; Willsman, A.; Fitzharris, B. Glacier response to climate change. Water Atmos. 2008, 16, 16-17.

61. Yang, J.; Liu, S.; Tan, C. Vulnerability of mountain glaciers in China to climate change. Adv. Clim. Chang. Res. 2015, 6, 171-180. [CrossRef]

62. Quincey, D.J.; Braun, M.; Glasser, N.F.; Bishop, M.P.; Hewitt, K.; Luckman, A. Karakoram glacier surge dynamics. Geophys. Res. Lett. 2011, 38. [CrossRef]

63. Alifu, H.; Tateishi, R.; Nduati, E.; Maitiniyazi, A. Glacier changes in Glacier Bay, Alaska, during 2000-2012. Int. J. Remote Sens. 2016, 37, 4132-4147. [CrossRef]

64. Owen, L.A.; England, J. Observations on rock glaciers in the Himalayas and Karakoram Mountains of northern Pakistan and India. Geomorphology 1998, 26, 199-213. [CrossRef]

(C) 2018 by the authors. Licensee MDPI, Basel, Switzerland. This article is an open access article distributed under the terms and conditions of the Creative Commons Attribution (CC BY) license (http://creativecommons.org/licenses/by/4.0/). 